\title{
İstanbul Maarif Sicilleri'nde gınâ-mûsiki muallimlerine ait biyografiler (1894-1931)
}

\section{Nuri Güçtekin*}

Sorumlu Yazar:

*T.C. Milli Eğitim Bakanlığı, İstanbul, Türkiye

Email: trakeagle@gmail.com, https://orcid.org/0000-0001-6115-5979

\begin{abstract}
Özet
İstanbul Milli Eğitim Müdürlüğü’nün Zeytinburnu Sicil Arșivi'ndeki 627 personele ait Osmanlıca (eski Türkçe) sicil dosyası ışığında ele alınan Maariften Milli Eğitime İstanbul Sicilleri (1878-1965) isimli üç ciltlik eser, aynı zamanda eğitimciler için yayımlanmış ilk bibliyografya özelliğini de ihtiva etmektedir. Bu çalıșmada ise neșredilen eser ıșığında, Osmanlı Devleti'nin son dönemi ile Cumhuriyetin ilk on yılına ait olmak üzere, İstanbul'daki ilk, orta ve lise kademesindeki resmî ve genel eğitim kurumlarında Gınâ, Gınâ-Mûsikî, ya da Mûsikî muallimi olarak devlet hizmetinde istihdam edilmiș olan 23 eğitimcinin biyografilerine yer verilmiștir. Yeni belge, bilgi ve bulgularla Türk Mûsikî Tarihi ve mekteplerdeki Gınâ/ Mûsikî eğitimi hakkında literatüre katkı sağlanmaya çalıșılmıștır.
\end{abstract}

\section{Anahtar kelimeler}

gınâ-mûsikî muallimi, türk mûsikî tarihi, gınâ-mûsikî eğitimi, faize ergin, laika karabey, kirkor mehteryan, kirkor çulhayan, arif hikmet bey

Osmanlı Devleti'nin klasik dönem temel eğitim kurumu medreselerdi. Kuruluș ve gelișme dönemlerinde, bulundukları devir itibariyle bașarılı olan medreseler Osmanlı Devleti'nin dünya devleti olmasında önemli rol oynamıșlardı. Osmanlı Devleti'nin Avrupaî tarzda reformlara tabi tutulduğu Tanzimat döneminde, yöneticilerin Batılı eğitim kurumları tercih etmesinin yanında, Avrupaî modeldeyeniaçılımların yapıldığısırada alternetifler üretemeyen medreselerin yetersizliği ve eski konumlarını koruyamaması önemli rol oynamıștır. Bu süreç ilk, orta ve lise seviyesinde olduğu gibi, Üniversite kademesinde de Avrupaî tarzda kurumların açılması ile neticelenmiștir (Arslan, 2004). Bir anlamda medreselerin sukutu Osmanlı Devleti'nin kendi medeniyeti çerçevesinde kurumlarını yenileyemeyen bașka yerlerden ithalat yaparak yeni kurumlar ortaya koyan bir devlet olmasına sebep olmuștur.

Eğitimde ilk batılılașma hareketleri, özellikle askerî alanda bașlayan yenilgilere bağlı olarak durumu tesine çevirmek için yapılan girișimler sonucunda, 1776-1839 yılları arasinda yapılmıștır. 1773 yılında deniz subayı yetiștirmek için Mühendishane-i Bahri-i Hümayun ve 1793 yılında kara subayı yetiștirmek için Mühendishane-i Berri-i Hümayun açılmıștır. 1827 yılında Tiphane-i Amire ve Cerrahhane- $i$ Mamure ve 1834 yılında Mekteb-i Ulum-i Harbiye adıyla subay okulu açılmıștır (Kaçar, 1996). Bu kurumlar 
bir anlamda Osmanlı'nın batıya açılan ilk pencereleri olmakla beraber diğer yandan Fransız Kültürü ve dilinin Osmanlı Devleti'nde nüfuz etmeye bașladığı ilk müseseseler olmușlardır. Bundan sonra eğitim alanında yapılan her yenilikte bu etki kendini gösterecektir.

1838 yılının Haziran ayında kurulan Meclis-i Umûr-i Nâfia ile sıbyan (mahalle), rüșdiye ve mekâtib-i aliye (yüksek) olmak üzere üç aşamalı bir yapı kurulmaya çalıșılmak istenmiștir. Amaçlanan sistem kurulamadığı gibi sıbyan mekteplerinin ıslahı ile rüșdiye mekteplerinin yaygınlaștırılmasında bașarısız olunmuștur. 1845 yılında önce Meclis-i Maarif ardından 20 Nisan 1857'de Maarif Nezareti olușturulmuștur (Akyıldız, 1993:249-258). 10 Şubat 1864 'te Meclis-i Maarif ikiye bölünerek biri özel okullar idaresi diğeri genel okullar idaresi olmuștur. Bu yapıya 1865 yılında Tercüme Dairesi eklenmiștir. Böylece yapılan düzenlemelerle eğitim müesseseleri ve teșkilatı tamamen devlet kontrolünde ve merkezden planlanan devlet kurumları haline gelmişlerdir.

1 Eylül 1869 tarihli Maarif-i Umumiye Nizamnamesi ile Osmanlı Devleti'nde eğitim ilk kez genel ve sistemli hale gelmiștir. Bu zamana kadar kurulmuș olan ve kurulması düşünülen okullar, bir eğitim sistemi çerçevesinde teșkilatlandırılmıștır. İlk defa vilayetlerde Maarif teșkilatı kurulmuştur. Mekâtib-i Umumiye yani resmî mektepler, sıbyan (daha sonra ibtidâi), rüșdiye, idadî, sultaniye ve yüksekokul olarak beș kısma ayrılırken; Mekâtib-i Hususiye yani özel mektepler Müslüman, gayrimüslim ve yabancılar tarafından açılan okullar olmak üzere üç kısma ayrılacaktır. Bu oluşturulan yapı Osmanlı Devleti'nin yıkılıșina kadar devam etmiștir (Güçtekin, 2015:62-65).

Bu nizamnamenin 29. Maddesinde; Kız Rüșdiye Mekteplerinin tahsil süresinin dört sene olduğu ve talim olunacak dersler içinde "mûsikî" mecburi değildir ibaresiyle yer almıștır. 69. ve 70 . maddelerinde de Dârülmuallimât Sıbyan ve Rüșdiye Șubesi'nde talim edilecek dersler içinde "mûsikî" dersi de yer almiștır (BOA, Y.EE, 112/6). Böylece ilk kez mûsikî dersi, müfredat programına dâhil olmuștur.

İstanbul'daki resmî ve özel eğitim kurumlarda, 1870-1908 yılları arasında mûsikî dersi verilmiștir. Fakihe Hanım, 23 Eylül 1883'den 29 Nisan 1887'e kadar piyona dersinin kaldırılmasına kadar İstanbul Dârülmuallimâtı Piyano muallimeliği yapmıștır (Personel Sicil No: 522). Kirkor Mehteryan, 1894-1914 yilları arasında Ermeni Mektepleri'nde 20 yıl gınâ ve nota muallimliği yapmıștır (Personel Sicil No: 536). İsmail Hakkı Bey (1866-1927), 1902-1905 yılları arasında Kadıköy'de Belediye Caddesinde eğitim veren Darülirfan Mektebi'nde mûsikî muallimi olarak görev yapmıștır. Bu okulda mûsikî dersleri; haftada 2 saat seçmeli ders olmak üzere dersler bittikten sonra akșamları okutulmuștur (Mükâfat Cetveli, 1902, 3-4). Zekâi Dede Efendi (1825-1897), 1883-1897 yılları arasında vefat edinceye kadar Darüșşafaka Mektebi'nde 14 yıl meșk sistemine dayalı mûsikî muallimliği yapmıștır (Özcan, 2013:195-196). Ondan sonra vazifeyi devralan oğlu Ahmet Irsoy (1869-1943), 1897-1943 yılları arasında 45 yıl mûsikî muallimi olarak görev yapmıștır (Özcan, 1999:131-133). Bu örnekleri çoğaltmak mümkündür. Ele alınan dönemde İstanbul'da batılı tarzda 
sistemli mûsikî dersleri verebilecek eğitim kurumları olsa da, tașra da ve örgün eğitim kurumlarında mûsikî dersini talep eden bir kitle henüz yoktur. Dersin seçmeli olması yanında, verilen emeğin maddi ve manevi getirisi çok azdır. Bu dönemde diğer önemli eksiklikte, mûsikî dersi verebilecek eğitimcinin yetișebileceği cemiyet ve müesseselerin talep görmemesiyle beraber maddi olanaksızlıklar dolayısıyla henüz tesis edilememiș olmasıdır.

23 Temmuz 1908'de Meșrutiyetin ilan edilmesiyle birlikte Osmanlı'da tüm toplum kesimleri hızlı bir örgütlenme sürecine girmișlerdir. Yüzlerce dernek kurulmuş ve yayınlar çıkartılmıștır. II. Meșrutiyet öncesinde; Enderûn, Mevlevihane, Mehter ve Muzıka-i Hümâyun'a bağlı dersliklerde görülen sistemli mûsikî dersleri ilk kez II. Meșrutiyet sonrasında açılan musiki cemiyetleri ve mekteplerinde verilmiștir. 1908 yılında mûsikî alanında açılan Dârülmûsikî-i Osmanî Cemiyeti; Osmanlı Devleti'ndeilkkurulanmûsikîcemiyetidir. Türk mûsikî üstatları ve mûsikî sevenler ilk kez Dârülmûsikî-i Osmanî Cemiyeti çatısı altında toplanmıștır. Kısa bir süre sonra 1909 yılının Mart ayında İsmail Hakkı Bey bu cemiyetten ayrılarak Mûsikî-i Osmanî Cemiyeti'ni kurmuștur. Böylece II. Meșrutiyet Dönemi'nde mûsikî faaliyetleri bu iki cemiyet aracılığıyla sürmüștür. 1910 yılında Mûsikî-i Osmanî Cemiyeti, 1912 yılında da Dârülmûsikî-i Osmanî Cemiyeti faaliyetlerine son vererek okul haline gelmişlerdir. Bu yıllar içinde bu cemiyetler; ücretli mûsikî dersi vermișler, İstanbul'da konser, eğlence ve müsamere düzenlemișlerdir. Ayrıca bu dönemin önemli ve ya zengin kişilerinin maddi desteği ile faaliyetlerini devam ettirmeye çalıșmışlardır. 1912-1914 yılları arasında Türk mûsikîsinin özellikle zenginlerin ve üst tabakanın rağbeti sonucunda gelișme göstermiștir. $\mathrm{Bu}$ dönemde mûsikî dersleri, konserleri, gece programları, okul sayıları ve faaliyetleri artmıștır. Türk mûsikîsinin bu gelișimi, I. Dünya Savașı'nın başlamasıyla sona ermiștir. Savaș dönemin çetin șartları, her alanda etkisini göstermiștir. Bundan Türk mûsikîsi de nasibini almıștır (Güçtekin, 2015:43).

Türk mûsikîsinin rağbet görmesinin neticesinde, Mûsikî dersi "Gınâ" adıyla tüm okullarda müfredatın bir parçası haline gelmesinde etkili olmuştur. 6 Ekim 1913'te Tedrisat- I Ibtidâiye Kanun-1 Muvakkati ile ilkokullar üç yıldan altı yıla çıkarılmıștır. İlköğretimde verilecek dersler arasında her sinıfta 1'er saat olmak üzere haftada altı saat Gınâ dersi yer almıștır (Düstûr, 1913). 1915 yılında Mekâtib-i Sultaniye Ders Programı'nda 6. 7. ve 8. sinıflarında 1 'er saat olmak üzere üç saat Gınâ dersi ilave edilmiștir (Maarif-i Umumiye Nezareti Telif ve Tercüme Dairesi, 1915:70)

$\mathrm{Bu}$ dersleri tedris edecek muallimlere mekteplerde okutmak için Gınâ/Mûsikî ders kitapları hazırlanmıștır. Böylece mûsikînin okullar kanalıyla tüm ülkeye yayılması sağlanmıștır. Ders saatinin artması ve zorunlu olması beraberinde bu dersleri verebilecek öğretmen sorununu doğurmuștur. Osmanlı Devleti'nde Gınâ/ Mûsikî muallim ya da muallime yetiștiren bir müessese olmaması dolayısıyla, mevcut açık Maarif Nezareti'nce açılan müsabaka imtihanları ya da Tedrisat- 1 Ibtidâiye Meclisi huzurunda yapilan imtihan neticesinde muallim ya da Ginâ/Mûsikî muallimeliği ehliyetnamesi alanların mekteplerde istihdam edilmesiyle çözümlenmiştir. 
Her vilayet ihtiyaç duyduğu branș ve dersten ehliyetname imtihanı açmıștır. İstanbul'daki mektepler de Mûsikî ya da Gınâ dersi verebilecek öğretmen sorunu daha az yașanırken tașra da münhal olan muallimlikler ilköğretimde sınıf öğretmenlerine ikinci görev ya da vekâleten verilmek yoluyla giderilmiștir.

10 Ocak 1917'de Osmanlı Devleti'nin ilk resmî müzik okulu olan Dârülelhan kurulmuștur. Kuruluş amacının, Türk ve Batı müziğini bilen ve bu alanda duyulan öğretmen ihtiyacını karșılamak olmakla beraber tasnif heyeti geçmiş mûsikî mirasımızı notaya alarak çok önemli bir görev üstlenmiștir. Dârülehân Mecmuası ise yayınladığı makaleler sayesinde Türk müziğinin akademik açıdan ele alınmasında ilk önemli adımı atmıștır (Özden, 2018).

1920'li yılların başlarına kadar mekteplerde imkân nispetinde Batı ve Türk müziği eğitimi beraber verilmeye çalıșılmıştır. Nota öğretimine devam edilirken meșkten de vazgeçilmeyerek iki metot da dengeliș șekilde verilmiștir (Toker ve Özden, 2013:120). Cumhuriyet'in kurulmasından hemen sonra örgün genel Mûsikî eğitimine büyük önem verilmiștir. Bunun temel gereği Mûsikî muallimi yetiștirme gereği ivedilikle ele alınmıștır. 1 Eylül 1924'te Ankara' da Mûsikî Muallim Mektebi kurulmuş ve 1 Kasım 1924 tarihinde öğretime açılmıştır (Şentürk, 2001:136). 1926'dan itibaren ortaokul ve liselerde Batı müziği eğitimini esas alan bir müfredatı belirlenerek dersler zorunlu hale getirmiștir (Toker ve Özden, 2013:122).

\section{Sinırlar ve metodoloji}

$\mathrm{Bu}$ çalıșma, İstanbul Milli Eğitim Müdürlüğü'nün Zeytinburnu Sicil
Arşivi'ndeki 627 personele ait Osmanlıca (eski Türkçe) sicil dosyası ıșığında ele alınan ve aynı zamanda eğitimciler için yayımlanmış ilk bibliyografya özelliğini de ihtiva eden; "Maariften Milli Eğitime İstanbul Sicilleri (1878-1965)" isimli eserdeki Gınâ/Mûsikî muallimliği yapmıș olan eğitimcilerin biyografilerine dayalı olarak hazırlanmıștır (Şakar ve Güçtekin, 2018). Bununla beraber Tanzimat'tan Cumhuriyet'in ilk on yılına kadarki Türk Mûsikî Tarihi ve mekteplerdeki Gınâ/ Mûsikî eğitimi hakkında Bașbakanlık Osmanlı Arşivi'nde bulunan Maarif Nezareti'ne ait dosya usulü evrakı ile diğer kaynaklarda bulunan literatür tespit edilmiștir.

Tüm bu bilgiler ıșığında çalıșmamız; muallimlerin almıș oldukları ehliyetname ve eğitime göre dört bölüm olarak ele alınmıștır. illk bölümde Gınâ ehliyetnamesi almıș olan, ikinci bölümde Mûsikî-i Rûhânî Birinci Sınıf Muallimlik Ehliyetnamesi almıș olanlar, üçüncü bölümde Mûsikî Muallimeliği Ehliyetnamesi almış olanlar ve dördüncü bölümde Mûsikî eğitimi almıș olan 23 Gınâ/Mûsikî mualliminin biyografisine yer verilmiștir. 9 adet belgeye yer verilmiş ve Ek-l'de sicil listesi tablosu hazırlanmiștır. Böylece alana yeni belge ve bilgilerle katkı sağlanmaya çalıșılmiștır.

\section{Gınâ Ehliyetnamesi Almıș Olanlar 1. Latife Hanım (1898 - ?)}

1898'de Bartın'da doğmuștur. Ahmed Efendi'nin kızıdır. İbtidâi tahsilini Çanakkale'de tamamladıktan sonra şahadetname alamadan İstanbul'a gelmiștir. Eğitimini, babasından aldığ 1 derslerle sürdürmüștür. 25 Ağustos 1916'da İstanbul Vilayeti Tedrisat-1 
imtihan neticesinde, mekâtib-i ibtidâiye gınâ muallimeliği ehliyetnamesi alarak özel Rehber-i Tahsil Mektebi'nde Keman ve Gınâ muallimeliği yapmıștır.

Dosyasında 16 Ekim 1923 tarihinden sonrasına ait kayıt bulunmamaktadır (Sicil Dosyası, No: 572).

Tablo 1. Çalıștığı kurumlar

\begin{tabular}{|c|c|c|c|c|}
\hline & Çalıştığı Mektepler ve Vazifesi & $\begin{array}{c}\text { Aldığı } \\
\text { Maaş } \\
\text { Aylık } \\
\text { Kuruş }\end{array}$ & $\begin{array}{c}\text { Göreve Başlama } \\
\text { ve Ayrılma Tarihleri }\end{array}$ & Açıklamalar \\
\hline 1 & $\begin{array}{l}\text { Hatice Sultan İnas Numune Mektebi Gınâ } \\
\text { Muallimeliği }\end{array}$ & 200 & 12 Şubat 1917-27 Eylül 1918 & Naklinden \\
\hline 2 & $\begin{array}{l}\text { Atik Ali Paşa Mektebi } \\
\text { Gınâ Muallimeliği }\end{array}$ & 300 & 16 Ekim 1918-1 Eylül 1919 & Nakil \\
\hline 3 & $\begin{array}{l}\text { Aynışah Sultan Numune Mektebi Gınâ } \\
\text { Muallimeliği }\end{array}$ & 300 & 11 Ekim 1918-20 Ocak 1919 & Naklinden \\
\hline 4 & $\begin{array}{l}\text { Davudpaşa Mektebi } \\
\text { Gınâ Muallimeliği }\end{array}$ & 200 & - & Başlamamıştır. \\
\hline 5 & Eyüb Mektebi Gınâ Muallimeliği & 300 & 1 Eylül 1919-19 Ekim 1921 & $\begin{array}{l}\text { Talebi üzerine } \\
\text { Nakil }\end{array}$ \\
\hline 6 & $\begin{array}{l}\text { Kıztaşı'nda Sultan Abdülaziz Han } \\
\text { Numune Mektebi Gınâ Muallimeliği }\end{array}$ & 300 & 23 Ekim 1921-4 Kasım 1921 & Naklinden \\
\hline 7 & Fatih Mektebi Gınâ Muallimeliği & 300 & 6 Kasım 1921-15 Ekim 1923 & $\begin{array}{l}\text { Hasbe't-teş- } \\
\text { kilat }\end{array}$ \\
\hline 8 & $\begin{array}{c}\text { Fatih, Sultan Abdülaziz Han ve Çelebi } \\
\text { Sultan Mehmed Mektepleri } \\
\text { Ginâ Muallimeliği }\end{array}$ & 600 & 16 Ekim 1923 & - \\
\hline
\end{tabular}

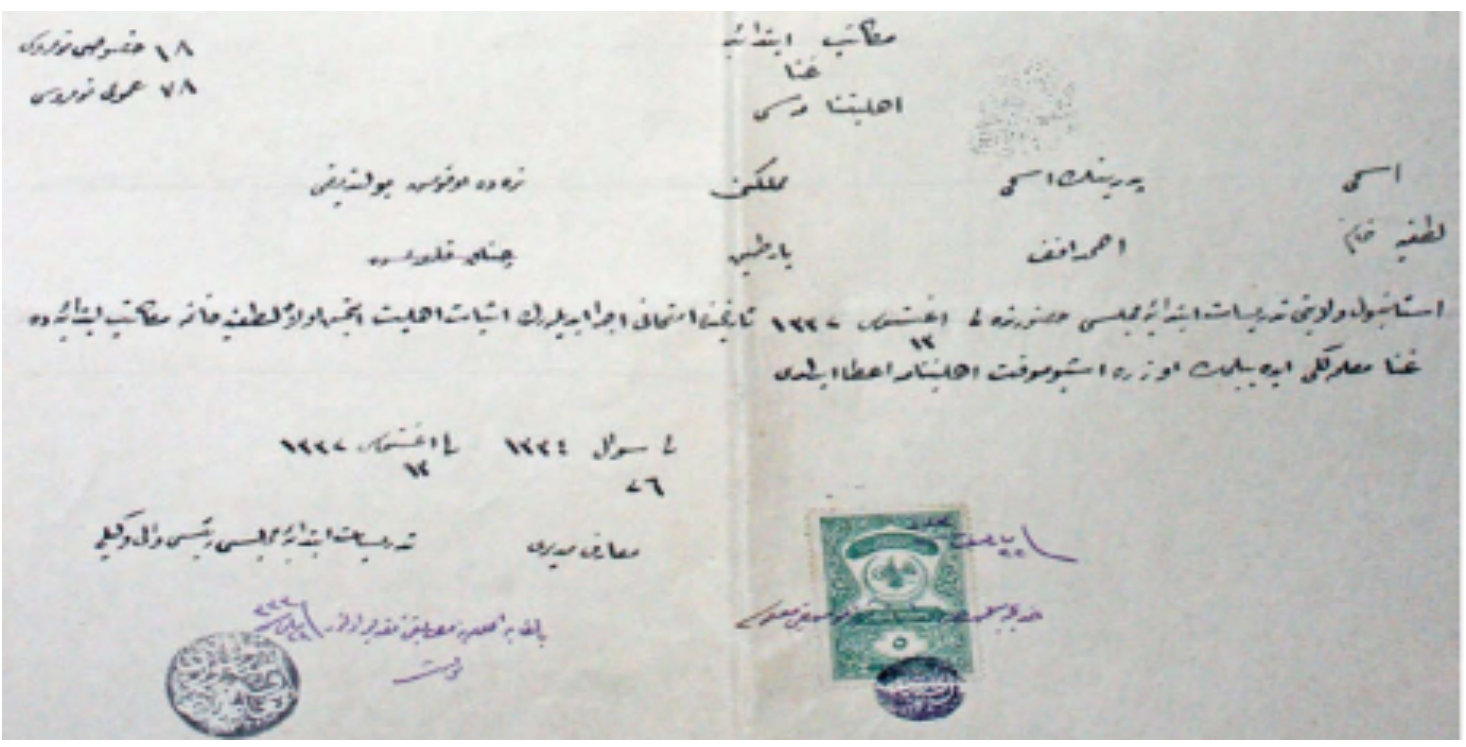

Belge 1. Latife Hanım'ın Mekâtib-i İbtidâiye Gınâ Muallimeliği Ehliyetnamesi (25 Ağustos 1916). 
2. Hasan Sadi Efendi (1894 - ?) 1894 'te Fatih civarında Manisalı Mehmed Paşa Mahallesi'nde doğmuştur. Mülkiye müfettișlerinden sabık Ma'mûretü'l-Azîz Valisi Manisalı Ali Seydi Bey'in oğludur. İbtidâi tahsilini Numune-i Terakki Mektebi'nde ikmal ettikten sonra 13 Eylül 1909'da İstanbul Leylî İdadîsi'nin rüșdiye 2. sınıfına kayıt yaptırmıștır. 26 Ağustos 1913'te İstanbul Mekteb-i Sultanîsi'nin 10. sınıfından tasdikname alarak mektebi terk etmiștir. İki sene Saint Benoit Mektebi'ne devam etmiş, ayrıca husûsi surette Fransızca dersleri almıștır. 1919'da Sanayi-i Nefise Mektebi'nden imtihanla ehliyetname almıștır. İki yıl Belçika'da bulunmuștur. Husûsi muallimlerden Mûsikî dersleri almıștır. Piyano, Keman ve tüm sazları tamamen ya da kısmen çalabilmektedir. 1922'de, İstanbul Vilayeti Tedrisat-1 İbtidâiye Meclisi huzurunda yapılan imtihan neticesinde, ibtidâi mekteplerde gınâ muallimliği yapabileceğine dair ehliyetname almıștır. Vazifesinden, 1 Ekim 1929'da istifa ederek ayrılmıștır (Sicil Dosyası, No: 12).

Tablo 2. Çalıștığı kurumlar

\begin{tabular}{|c|c|c|c|c|}
\hline SN & Çalıştığı Mektepler ve Vazifesi & $\begin{array}{l}\text { Aldığı } \\
\text { Maaş } \\
\text { Aylık } \\
\text { Kuruş }\end{array}$ & $\begin{array}{c}\text { Göreve Başlama } \\
\text { ve Ayrılma Tarihleri }\end{array}$ & Açıklamalar \\
\hline 1 & $\begin{array}{c}\text { Akşemseddin- Kırımî Hacı } \\
\text { Arslan Bey Numune Mektebi } \\
\text { Gınâ Muallimliği }\end{array}$ & 200 & 20 Eylül 1922-15 Ekim 1923 & $\begin{array}{l}\text { Müsabakadaki } \\
\text { ehliyetsizli- } \\
\text { ğinden açıkta } \\
\text { kalmıştır. }\end{array}$ \\
\hline 2 & $\begin{array}{c}\text { Mahmud Şevket Paşa } \\
\text { Numune Mektebi Gınâ } \\
\text { Muallimliği }\end{array}$ & 600 & 21 Ekim 1924-21 Mart 1926 & $\begin{array}{l}\text { Maaşına zam } \\
\text { almıştır. }\end{array}$ \\
\hline 3 & $\begin{array}{l}\text { İstanbul 3. Illk Mektebi } \\
\text { Mûsikî Muallimliği }\end{array}$ & 1.500 & 22 Mart 1926-1 Ekim 1929 & İstifa etmiştir. \\
\hline
\end{tabular}
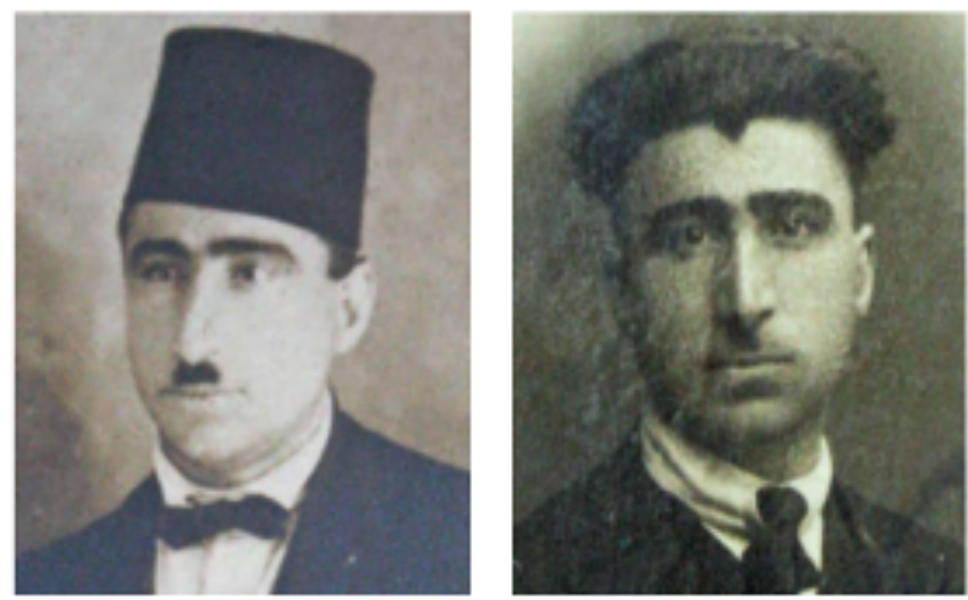

Resim 1. Hasan Sadi Efendi. 


\section{Fatma Kadriye Hanım (15}

Ocak 1901 - ?)

15 Ocak 1901'de İstanbul'da doğmuștur. Hassa Nakliye Taburu Demircibașısı merhum Mehmed Efendi'nin kızıdır. İstanbul Dârülmuallimât-ı Âliyesi'nin ibtidâi kısmını bitirerek 20 Ekim 1921'de aliyyü'l-a'lâ derecede şahadetname almıștır. Dârülelhan Mûsikî Encümeni'nce açılan imtihan neticesinde, ibtidâi mekteplerde gınâ dersi verme hakkı kazanmıştır (26 Ağustos 1922). 26 Mart 1927'de Edremit 1. Kız Mektebi'nde görev yapmaktadır (Sicil Dosyası, No: 20).

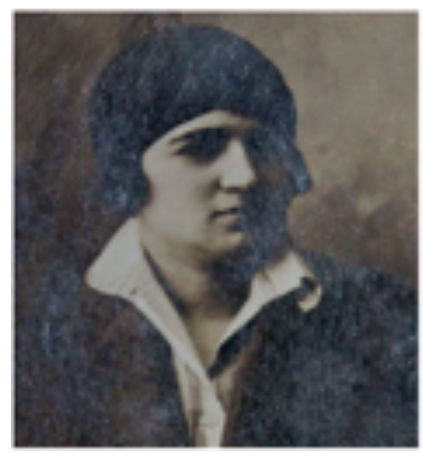

Resim 2. Fatma Kadriye Hanım.

Tablo 3. Çalıștığı kurumlar

\begin{tabular}{|c|c|c|c|c|}
\hline SN & Çalıştığı Mektepler ve Vazifesi & $\begin{array}{c}\text { Aldı̆̆ı } \\
\text { Maaş } \\
\text { Aylık } \\
\text { Kuruş }\end{array}$ & $\begin{array}{c}\text { Göreve Başlama } \\
\text { ve Ayrılma Tarihleri }\end{array}$ & Açıklamalar \\
\hline $\mathbf{1}$ & $\begin{array}{c}\text { Mahfiruz Sultan İnas Numune } \\
\text { Mektebi Muallimeliği }\end{array}$ & 600 & 8 Ekim 1922-30 Kasım 1923 & $\begin{array}{c}\text { Yeni tayin } \\
\text { ve nakil }\end{array}$ \\
\hline $\mathbf{2}$ & $\begin{array}{c}\text { Eğrikapı Numune Mektebi } \\
\text { Şube Muallimeliği }\end{array}$ & 700 & 1 Aralık 1923-22 Ocak 1924 & $\begin{array}{c}\text { Yaş hasebiyle } \\
\text { nakil }\end{array}$ \\
\hline $\mathbf{3}$ & $\begin{array}{c}\text { Mahfiruz Sultan Mektebi } \\
\text { Muallimeliği }\end{array}$ & 700 & 27 Ocak 1924-16 Kasım 1924 & $\begin{array}{c}\text { Edremit'e } \\
\text { gideceğinden } \\
\text { istifa etmiştir. }\end{array}$ \\
\hline
\end{tabular}

4. Zeliha Nezahat Hanım (23 Nisan 1896 - ?)

23 Nisan 1896'da İstanbul'da doğmuștur. Topçu Kaymakamlarından Osman Ferid Bey'in kızıdır. Özel eğitim almıștır.

Tablo 4. Çalıștığı kurumlar
1 Kasım 1920'de, Maarif-i Umumiye Nezareti Mûsikî Encümeni'nden mekâtib-i ibtidâiye gınâ muallimeliği ehliyetnamesi almıștır. 29 Eylül 1926'da vazifesinden istifa etmiștir (Sicil Dosyası, No: 957).

\begin{tabular}{|c|c|c|c|c|}
\hline SN & Çalıştığı Mektepler ve Vazifesi & $\begin{array}{c}\text { Aldığı } \\
\text { Maaş } \\
\text { Aylık } \\
\text { Kuruş }\end{array}$ & $\begin{array}{c}\text { Göreve Başlama } \\
\text { ve Ayrılma Tarihleri }\end{array}$ & Açıklamalar \\
\hline $\mathbf{1}$ & $\begin{array}{c}\text { Kocamustafapaşa İnas Numune } \\
\text { Mektebi Gınâ Muallimeliği }\end{array}$ & 300 & 21 Nisan 1923-15 Ekim 1923 & Teşkilatta nakil \\
\hline $\mathbf{2}$ & $\begin{array}{c}\text { Moda'da Murad-1 Hamis ve Bostan- } \\
\text { c1 Mektebi Gnâ Muallimeliği }\end{array}$ & 600 & 16 Ekim 1923-6 Eylül 1924 & Nakil \\
\hline $\mathbf{3}$ & $\begin{array}{c}\text { Mahfiruz Mektebi } \\
\text { Ginâ Muallimeliği }\end{array}$ & 600 & 1 Ekim 1924-25 Eylül 1926 & Naklinden \\
\hline $\mathbf{4}$ & Beyoğlu 4. Mektep Muallimeliği & 1.500 & 25 Eylül 1926-29 Eylül 1926 & İstifa etmiştir. \\
\hline
\end{tabular}


5. Emine Ruhsar Hanım (24 Ağustos 1885 - ?)

24Ağustos 1885'te İstanbul'da doğmuștur. Mülga Harbiye Nezareti Levazım 1. Şube mümeyyizlerinden Hüseyin Hüsnü Bey'in kızıdır. Türkçe ulum ve fünunu husûsi surette tahsil etmiștir. Şark Mûsikî Cemiyeti konser heyetinde yer alması dolayısıyla, 11 Ekim 1922'de Maarif-i Umumiye Nezareti Mûsikî Encümeni'nden mekâtib-i taliye ve aliyede gınâ muallimeliği yapabileceğine dair ehliyetname almıștır. Keman ve piyanoda talim ve tedrise muktedir olduğu 12 Ekim 1922'de -konser heyeti azasından olduğu- Şark Mûsikî Cemiyeti'nce de tasdik edilerek șahadetname verilmiștir. 16 Ekim 1923'te, vazifesine gelmediği için müstafi sayılmıștır (Sicil Dosyası, No: 22).

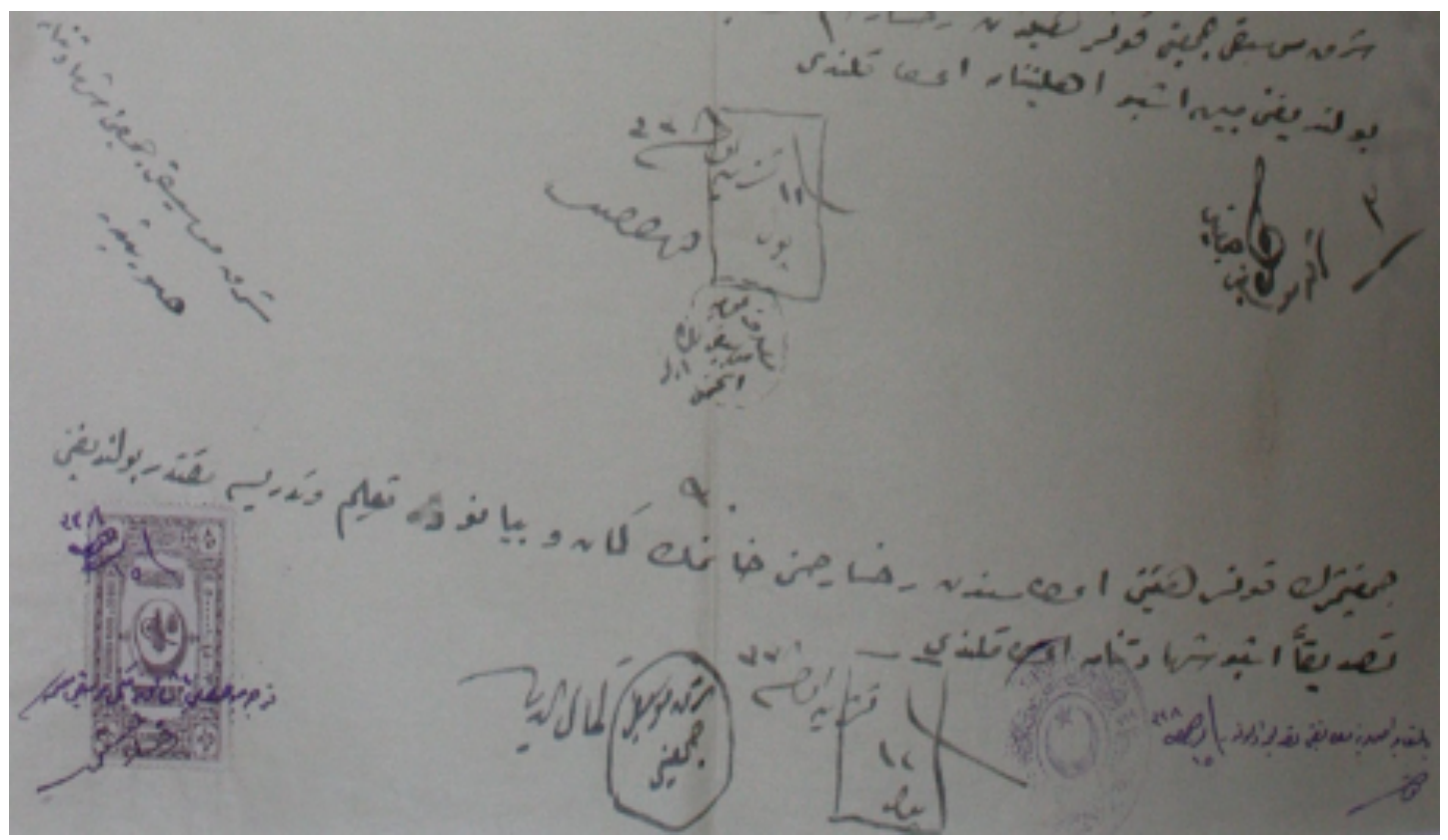

Belge 2. Ruhsar Hanım'ın Şark Mûsikî Cemiyeti Şahadetnamesi (12 Ekim 1922).

Tablo 5. Çalıștığı kurumlar

\begin{tabular}{|c|c|c|c|c|}
\hline SN & Çalıştı̆̆ı Mektepler ve Vazifesi & $\begin{array}{c}\text { Aldığı } \\
\text { Maaş } \\
\text { Aylık } \\
\text { Kuruş }\end{array}$ & $\begin{array}{c}\text { Göreve Başlama } \\
\text { ve Ayrılma Tarihleri }\end{array}$ & Açıklamalar \\
\hline $\mathbf{1}$ & $\begin{array}{c}\text { Kocamustafapaşa İnas Numune } \\
\text { Mektebi Gı̂a Muallimeliği }\end{array}$ & 300 & 11 Ekim 1922-20 Nisan 1923 & $\begin{array}{c}\text { Yaş itibarıyla } \\
\text { naklinden }\end{array}$ \\
\hline $\mathbf{2}$ & $\begin{array}{c}\text { Mahfiruz Sultan Mektebi } \\
\text { Ginâ Muallimeliği }\end{array}$ & 300 & 22 Nisan 1923-16 Ekim 1923 & $\begin{array}{c}\text { Müstafi } \\
\text { sayıldığından }\end{array}$ \\
\hline
\end{tabular}

6. Sabuncuzade Hatice Faize ERGiN (12 Haziran 1894 -21 Şubat 1954) 12 Haziran 1894 'de İstanbul'da doğmuștur. Sultan Abdülhamid-i Sani'nin mabeyincilerinden Hasan Faik Bey'in kızıdır. Annesi Șeminur Hanım'dır. İbtidâi ve tali tahsillerini husûsi muallimlerden almıștır. Tanburu Tanburi Cemil Bey'den, fenn-i mûsikîyi Enderunî Hafız Hüsnü Efendi'den öğrenmiștir. Maarif 
Nezareti'nce açılan Dârülelhan- I Osmanî muallim ve muallimelik müsabakasına katılmıș; 1 Eylül 1917'de 600 kuruș maașla Dârülelhan tanbur muallimeliğine tayin olunmuștur. Dârülelhan İnas Kısmı tanbur muallimeliğinde bulunan Faize Hanım'a, 29 Temmuz 1922'de, Maarif-i Umumiye Nezareti Mûsikî Encümeni'nce mekâtib-i taliye ve aliyede ginâ muallimeliği yapabileceğine dair ehliyetname verilmiștir. 1923'te, maașı 800 kurușa yükseltilerek Şark Şubesi'nin tanbur muallimeliği kadrosuna nakledilmiștir. 1 Eylül 1923'te maașı 4.000 kuruşa yükselmiștir. 28 Şubat 1925'te, talebe azlığından vazifesinin diğer tanbur muallimleri arasında paylaștırılip kadrosunun lağvedilmesinden dolayı ayrılmıștır. Notalardan olușan yayımlanmıș bir eseri bulunmaktadır. Piyano, keman ve tanbur çalmakta olup İngilizce ve Fransızca bilmektedir. Dosyasinda, 19 Temmuz 1928 tarihinden sonrasına ilișkin kayıt bulunmamaktadır (Sicil Dosyası, No: 25). Maarif müfettișlerinden Ruhi Bey ile evliydi. Ergin soyadını almıștır. 21 Şubat 1954'te İstanbul'da vefat etmiștir (2017, Eylül 1).

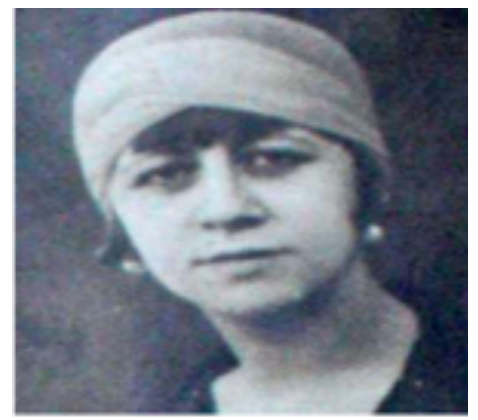

Resim 3.Faize Ergin.

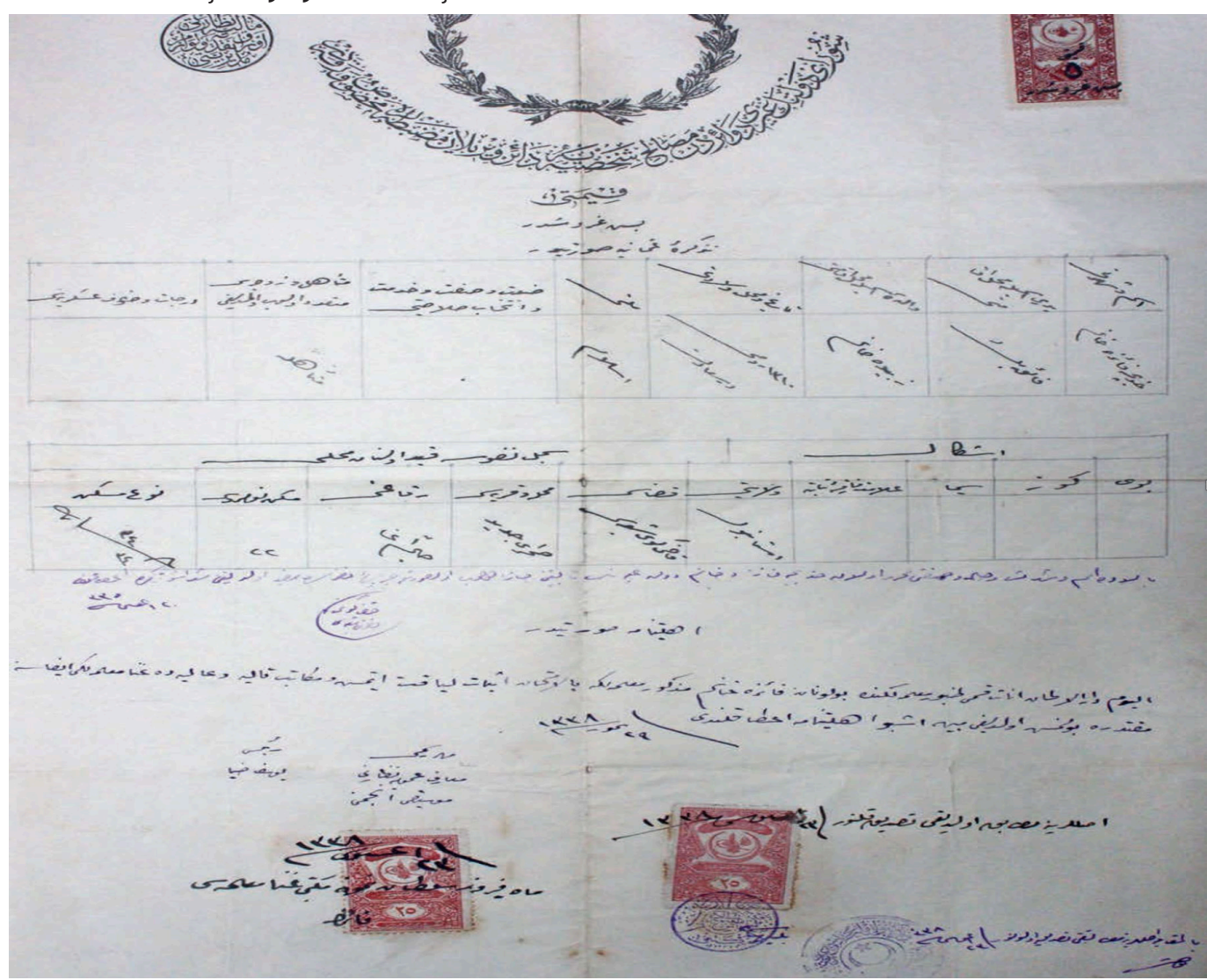

Belge 3.Faize Hanım’ın Maarif Nezareti Mûsikî Encümeni Gınâ Muallimeliği Ehliyetnamesi (29 Temmuz 1922). 
Tablo 6. Faize Ergin'nin çalıștığı kurumlar

\begin{tabular}{|c|c|c|c|c|}
\hline SN & $\begin{array}{c}\text { Çalıştığı Mektepler ve } \\
\text { Vazifesi }\end{array}$ & $\begin{array}{c}\text { Aldığı Maaş } \\
\text { Aylık Kuruş }\end{array}$ & $\begin{array}{c}\text { Göreve Başlama } \\
\text { ve Ayrılma Tarihleri }\end{array}$ & Açıklamalar \\
\hline $\mathbf{1}$ & $\begin{array}{c}\text { Mahfiruz Sultan İnas Numune } \\
\text { Mektebi Gınâ Muallimeliği }\end{array}$ & 300 & 3 Aralık 1921-21 Nisan 1923 & $\begin{array}{c}\text { Talebi üzerine } \\
\text { nakil }\end{array}$ \\
\hline $\mathbf{2}$ & $\begin{array}{c}\text { Moda İnas Numune Mektebi } \\
\text { Gınâ Muallimeliği }\end{array}$ & 300 & 22 Nisan 1923-15 Ekim 1923 & Açıkta kalmıştır. \\
\hline $\mathbf{3}$ & $\begin{array}{c}\text { Moda İnas Numune Mektebi } \\
\text { Gı̂â Muallimeliği }\end{array}$ & 800 & 2 Ocak 1926-22 Mart 1926 & Kanunen zam \\
\hline $\mathbf{3}$ & Moda 8. Mektep Muallimeliği & 1.725 & 22 Mart 1926-1 Ekim 1927 & Naklinden \\
\hline $\mathbf{4}$ & $\begin{array}{c}\text { Üsküdar 11. Mektep } \\
\text { Mûsikî Muallimeliği }\end{array}$ & 1.725 & 1 Ekim 1927-19 Temmuz & $\begin{array}{c}\text { Görevine devam } \\
\text { etmektedir. }\end{array}$ \\
\hline
\end{tabular}

Tablo 7. Şemiye Hanım'ın çalıștığı kurumlar

\begin{tabular}{|c|c|c|c|c|}
\hline SN & Çalıştığı Mektepler ve Vazifesi & $\begin{array}{c}\text { Aldığı Maaş } \\
\text { Aylık Kuruş }\end{array}$ & $\begin{array}{c}\text { Göreve Başlama } \\
\text { ve Ayrılma Tarihleri }\end{array}$ & Açıklamalar \\
\hline $\mathbf{1}$ & $\begin{array}{c}\text { Beşiktaş’ta Mihrimah Sultan } \\
\text { İnas Numune Mektebi } \\
\text { Mûsikî Muallimeliği }\end{array}$ & 300 & 4 Mart 1923-1 Haziran & Devam etmektedir. \\
& & 1923 & \\
\hline
\end{tabular}

7. Şemiye Hanım (1900 - ?)

1900 yılında İstanbul Beșiktaș’ta doğmuştur. Dolmabahçe Gazhane ketebesinden Abdurrahman Efendi'nin kızıdır. Husûsi surette tahsil görmüștür. Dârülelhan İnas Kısmı fasl-ı mûsikî heyetinde yer alan Şemiye Hanım'a, 5 Temmuz 1922'de Maarif-i Umumiye Nezareti Mûsikî Encümeni tarafından, ibtidâi ve tali mekteplerde gınâ talimine muktedir olduğuna dair ehliyetname verilmiștir. Dosyasında 1 Haziran 1923 tarihinden sonrasına ilișkin kayıt bulunmamaktadır (Sicil Dosyası, No: 65).

\section{Laika KARABEY (1905 - 20 Aralık 1989)}

1905'te Suudi Arabistan'ın Asir Şehri'nde doğmuștur. Merhum Miralay Hasan Tahsin Bey'in kızıdır. 1907-1908 ders yılı bașında, Üsküdar Midhat Paşa Kız Sanayi Mektebi'nin 7. sınıfından tasdikname alarak mektebi terk etmiștir. Kadıköy Şark Mûsikî Cemiyeti aza-yı asliyesinden olup 8 Ocak 1922'de Dârülelhan'ın İnas Kısmı Müdüriyeti'nden mekâtib-i ibtidâiye ve taliyede gınâ dersi verebileceğine dair tasdikname almıștır. Müziğin ameliyat ve nazariyatına (teori ve pratiğine) ders verecek derecede vâkıf ve hüsn-i ahlak ve iffet ashabından olduğu, 8 Ocak 1922'de, azaları içerisinde ve konser heyetinde yer aldığı Şark Mûsikî Cemiyeti'nce de tasdik edilmiștir. Tanburi Cemil Bey -merhumile tanburi Hikmet Bey'den tanbur dersleri almıștır. Gınâ dersini piyano ile verebilme yeteneği vardır.

Dosyasında 16 Ekim 1923 tarihinden sonrasına ilișkin kayıt bulunmamaktadır (Sicil Dosyası, No: 940). Tercüme-i hal varakasında adını "Emine Laika" olarak yazmıștır. Emin Arifi Bey’le evlenerek Karabey soyadını almıștır. 20 Aralık 1989'da İstanbul'da vefat etmiștir (2017, Eylül 1). Arşivi İBB Atatürk Kitaplığı/Belediye Kütüphanesi'nde bulunmaktadır. 
İstanbul Maarif Sicilleri'nde gınâ-mûsiki muallimlerine ait biyografiler (1894-1931)

Tablo 8. Laika Hanım'ın çalıștığı kurumlar

\begin{tabular}{|c|c|c|c|c|}
\hline SN & Çalıştığı Mektepler ve Vazifesi & $\begin{array}{c}\text { Aldığı Maaş } \\
\text { Aylık Kuruş }\end{array}$ & $\begin{array}{c}\text { Göreve Başlama } \\
\text { ve Ayrılma Tarihleri }\end{array}$ & Açıklamalar \\
\hline $\mathbf{1}$ & $\begin{array}{c}\text { Halıcıoğlu'nda Sultan Mahmud } \\
\text { Han-1 Sani İnas Numune } \\
\text { Mektebi Gınâ Muallimeliği }\end{array}$ & 300 & 26 Şubat 1923-15 Ekim 1923 & Naklinden \\
\hline $\mathbf{2}$ & $\begin{array}{c}\text { Köprülü Mehmed Paşa ve } \\
\text { Orhangazi Mektepleri } \\
\text { Gınâ Muallimeliği }\end{array}$ & 600 & 16 Ekim 1923- & $\begin{array}{c}\text { Devam } \\
\text { etmektedir. }\end{array}$ \\
\hline
\end{tabular}
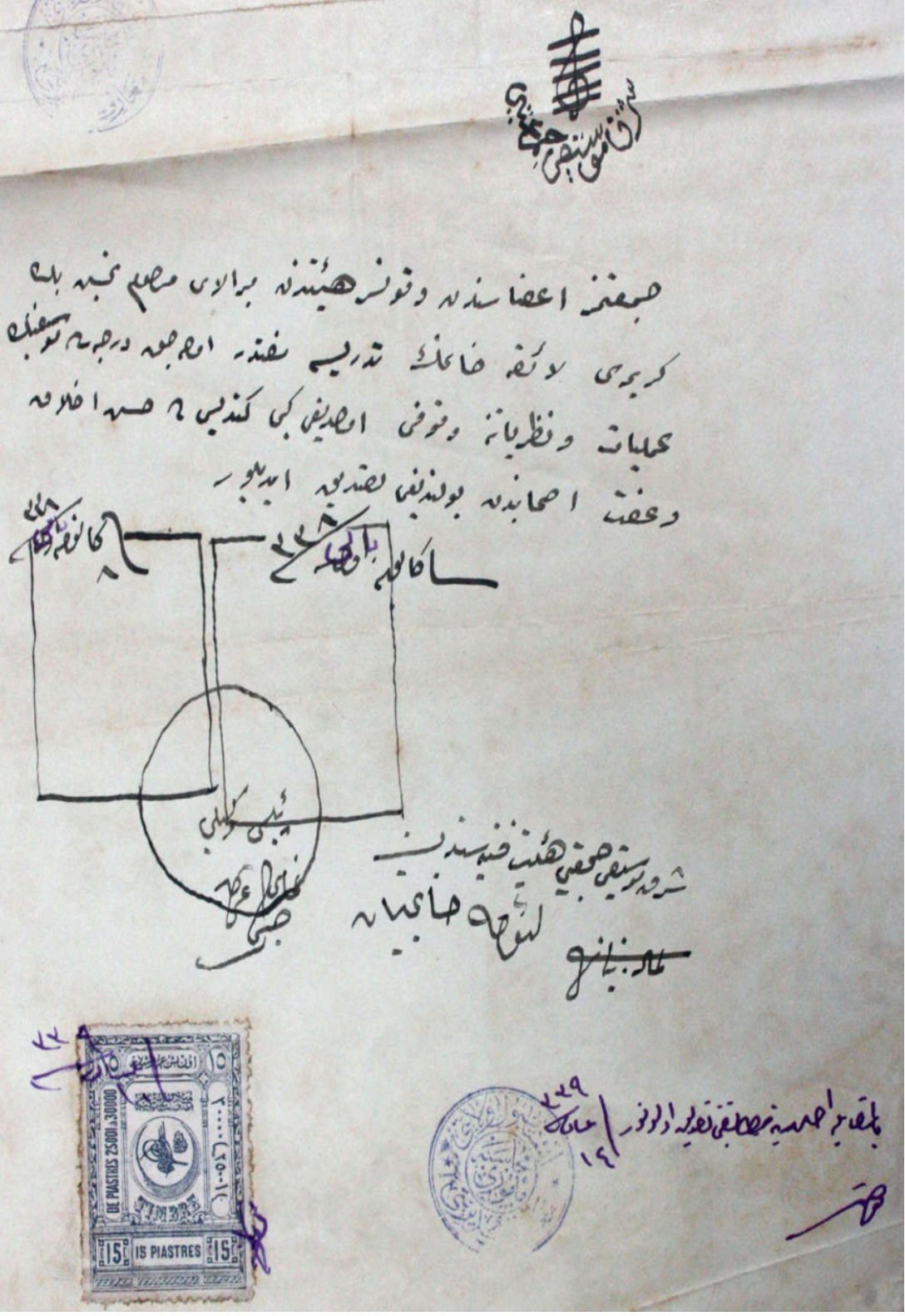

Belge 5. Laika Karabey’in Şark Mûsikî Cemiyeti Onay Belgesi (8 Ocak 1922). 


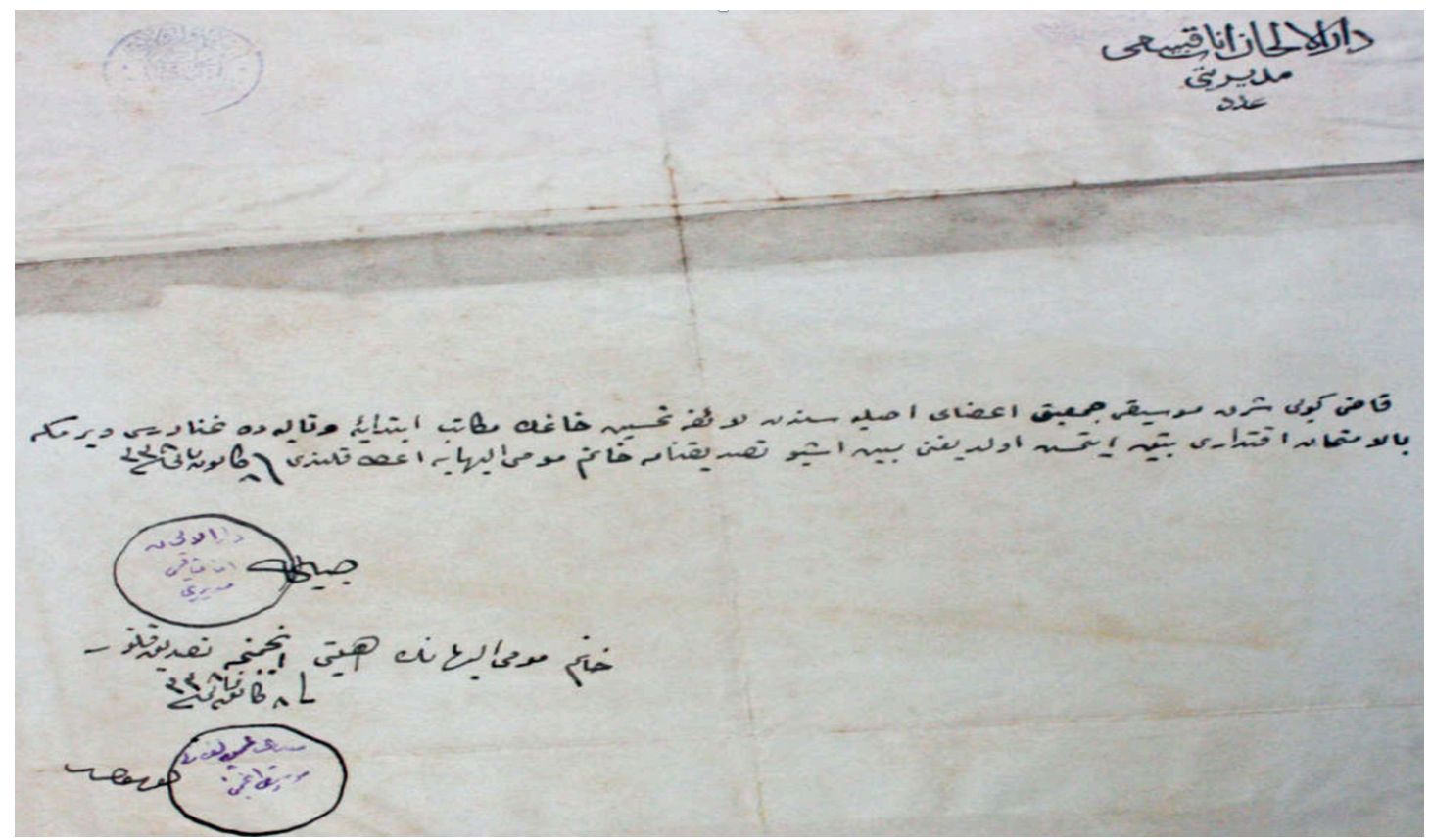

Belge 4. Laika Karabey’in Dârülelhan İnas Kısmı Müdüriyeti Tasdiknamesi (8 Ocak 1922).

9. Hüsnihal Hanım (1881 - ?) 1881'de Kirmastı Kasabası'nda doğmuștur. Esnaftan -merhum- İshak Efendi'nin kızıdır. Dârülelhan'ın İnas kısmının fasl- mûsikî heyetinden olup 5 Mayıs 1922'de Maarif-i Umumiye Nezareti Mûsikî Encümeni'nden mekâtib-i ibtidâiyede gınâ talim ve tedrisine liyakatı olduğuna dair ehliyetname almıștır. Özel Piyano, Ud, Kanun ve Keman eğitimi almıștır. 1 Kasım 1929'da, kursta bașarılı olamadığından görevine son verilmiștir. Hizmet süresi 17 sene 7 ay 25 gündür (Sicil Dosyası, No: 501).

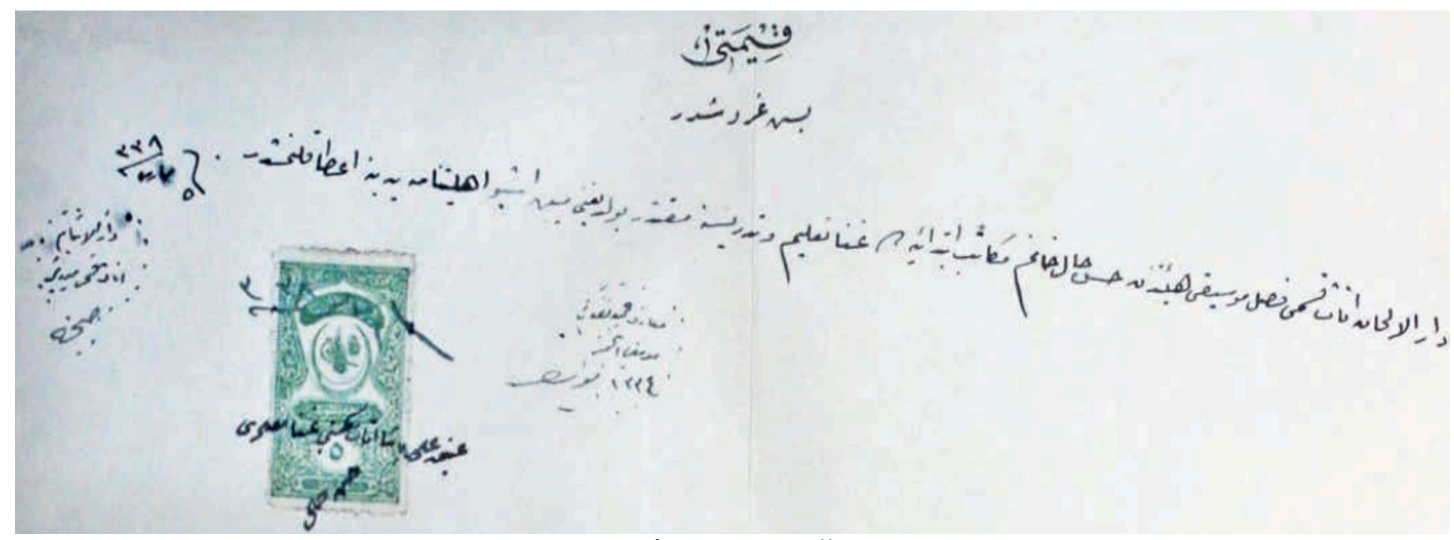

Belge 6. Hüsnihal Hanım'ın Gınâ Muallimeliği Ehliyetnamesi (5 Mayıs 1922). 
Tablo 9. Hüsnihal Hanım'ın çalıștığı kurumlar

\begin{tabular}{|c|c|c|c|c|}
\hline SN & Çalıştığı Mektepler ve Vazifesi & $\begin{array}{c}\text { Aldığı } \\
\text { Maaş } \\
\text { Aylık } \\
\text { Kuruş }\end{array}$ & $\begin{array}{c}\text { Göreve Başlama } \\
\text { ve Ayrılma Tarihleri }\end{array}$ & Açıklamalar \\
\hline 1 & $\begin{array}{c}\text { Beylerbeyi İnas Numune Mektebi } \\
\text { Gınâ Muallimeliği }\end{array}$ & 300 & $\begin{array}{l}24 \text { Ekim } 1915-17 \text { Ekim } \\
1916\end{array}$ & Naklinden \\
\hline 2 & $\begin{array}{l}\text { Paşabahçe ve Kandilli Lisesi } \\
\text { Gınâ Muallimeliği }\end{array}$ & 700 & 18 Ekim 1916-1 Eylül 1917 & Nakil \\
\hline 3 & $\begin{array}{l}\text { Beykoz, Beylerbeyi ve Kanlıca } \\
\text { Mektepleri Gınâ Muallimeliği }\end{array}$ & 900 & 1 Eylül 1917-25 Ekim 1921 & Naklinden \\
\hline 4 & $\begin{array}{l}\text { Atik Ali Paşa İnas Mektebi } \\
\text { Mûsikî Muallimeliği }\end{array}$ & 300 & $\begin{array}{l}26 \text { Ekim 1921-15 Ekim } \\
1923\end{array}$ & Teşkilatta nakil \\
\hline 5 & $\begin{array}{l}\text { Harmanlık, Nakkaştepe ve Beylerbeyi } \\
\text { Mektepleri Mûsikî Muallimeliği }\end{array}$ & 900 & $\begin{array}{l}16 \text { Ekim 1923-30 Eylül } \\
1924\end{array}$ & $\begin{array}{l}\text { Hasbe't-teş- } \\
\text { kilat }\end{array}$ \\
\hline 6 & $\begin{array}{l}\text { Beylerbeyi Mektebi } \\
\text { Mûsikî Muallimeliği }\end{array}$ & 900 & 1 Ekim 1924-21 Mart 1926 & Maaşına zam \\
\hline 7 & $\begin{array}{l}\text { Beylerbeyi 27. İlk Kiz Mektebi } \\
\text { Mûsikî Muallimeliği }\end{array}$ & 1.740 & 22 Mart 1926-1 Kasım 1929 & $\begin{array}{l}\text { Kursta başarılı } \\
\text { olamadığından }\end{array}$ \\
\hline
\end{tabular}

\section{Mûsikî-i Rûhânî Birinci Sınıf Muallimlik Ehliyetnamesi Almıș Olanlar}

\section{Kirkor Mehteryan Efendi}

\section{(1868 - 1937)}

1871'de İstanbul Kumkapı'da doğmuștur. Ermeni tebaasından marangoz Sarkis Mehteryan Efendi'nin oğludur. Kumkapı Patrikhanesi İdadîsi'nde eğitim görerek 1886'da aliyyü'l-a'lâ derecede șahadetname ile mezun olmuștur. Şahadetnamesi Yenikapı Yangını'nda zayi olmuștur. 31 Mayıs 1912'de Dersaadet Ermeni Patrikhanesi Maarif Komisyonu kararıyla Mûsikî-i Rûhânî Birinci Sinıf Muallimlik Ehliyetnamesi verilmiștir. 1886'dan 1894'e kadar özel mûsikî dersleri vermenin yanı sıra, ünlü müzisyenlerden Çuhaciyan, Hamparsum, Astik ve Tatyos Efendilerden ikmal-i zanaat eylemiștir. 13 Eylül 1894'ten bașlayarak Ermeni Mektepleri'nde 20 yıl gınâ ve nota muallimliği yaptıktan sonra 14 Ekim 1914'te Kocamustafapașa Zükûr
Numune Mektebi mûsikî muallimliğine tayin edilerek devlet hizmetine alınmıștır. Türkçe ve Fransızca bilmektedir. Dosyasında 29 Aralı 1922 tarihinden sonrasına ilișkin kayıt bulunmamaktadır. 1937'de Kahire'de vefat etmiștir (Sicil Dosyası, No: 536).

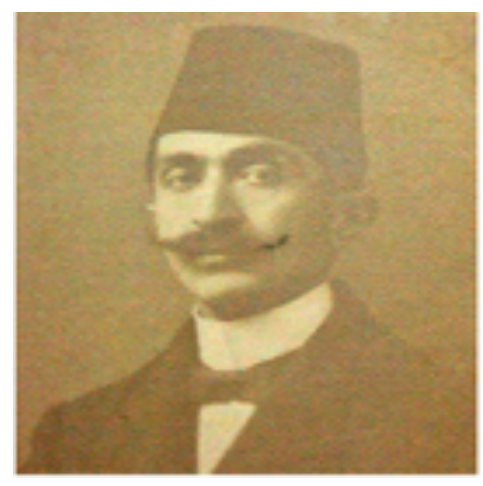

Resim 4.Kirkor Mehteryan Efendi. 
Tablo 10. Kirkor Mehteryan Efendi'nin çalıștığı kurumlar

\begin{tabular}{|c|c|c|c|c|}
\hline $\mathbf{S N}$ & Çalıştığı Mektepler ve Vazifesi & $\begin{array}{l}\text { Aldığı Maaş } \\
\text { Aylık Kuruş }\end{array}$ & $\begin{array}{c}\text { Göreve Başlama } \\
\text { ve Ayrılma Tarihleri }\end{array}$ & Açıklamalar \\
\hline 1 & $\begin{array}{l}\text { Patrikhane Mektebi } \\
\text { Mûsiki Muallimliği }\end{array}$ & 500 & 13 Eylül 1894-16 Nisan 1915 & $\begin{array}{l}\text { Devam etmek- } \\
\text { tedir. }\end{array}$ \\
\hline 2 & $\begin{array}{c}\text { Yedikule Ermeni Darüleytamı Mûsiki } \\
\text { Muallimliği }\end{array}$ & 200 & 13 Eylül 1896-1899 & Ayrılmıştır. \\
\hline 3 & $\begin{array}{c}\text { Kadıköy Ermeni Aramyan Mektebi Mûsiki } \\
\text { Muallimliği }\end{array}$ & 200 & $1897-1900$ & Ayrılmıştır. \\
\hline 4 & $\begin{array}{l}\text { Makrıköy Ermeni Mektebi } \\
\text { Mûsiki Muallimliği }\end{array}$ & 200 & 1899-1914 & İstifa etmiştir. \\
\hline 5 & $\begin{array}{l}\text { Kadıköy Ermeni İdadîsi } \\
\text { Mûsiki Muallimliği }\end{array}$ & 200 & $1910-1913$ & İstifa etmiştir. \\
\hline 6 & $\begin{array}{c}\text { Kocamustafapaşa Zükûr Numune Mektebi } \\
\text { Mûsiki Muallimliği }\end{array}$ & 200 & 14 Ekim 1914-13 Ocak 1916 & Yeni tayin \\
\hline 7 & $\begin{array}{c}\text { Kocamustafapaşa ve Ertuğrul Numune } \\
\text { Mektepleri } \\
\text { Mûsiki Muallimliği }\end{array}$ & 800 & 14 Ocak 1916-25 Ağustos 1915 & İlave tayin \\
\hline 8 & $\begin{array}{l}\text { Kabasakal Mektebi Zükûr ve İnas Sınıfları } \\
\text { Gınâ Muallimliği }\end{array}$ & 300 & 28 Eylül 1916-12 Şubat 1917 & Tayin \\
\hline 9 & $\begin{array}{l}\text { Selahaddin Eyyubi Mektebi Zükûr ve İnas } \\
\text { Sınıfları Gınâ Muallimliği }\end{array}$ & 300 & 28 Eylül 1916-14 Temmuz 1919 & Teşkilatta açıkta \\
\hline 10 & Kadıköy Mektebi Gınâ Muallimliği & 200 & 17 Şubat $1917-11$ Ocak 1918 & Naklinden \\
\hline 11 & $\begin{array}{l}\text { Siyavuş Paşa Mektebi } \\
\text { Gınâ Muallimliği }\end{array}$ & 350 & 16 Eylül 1917-14 Temmuz 1919 & Teşkilatta ibka \\
\hline 12 & $\begin{array}{l}\text { Sokullu Mehmed Paşa Numune Mektebi } \\
\text { Gınâ Muallimliği }\end{array}$ & 200 & 1 Ocak 1918-20 Ekim 1918 & $\begin{array}{l}\text { Kadronun tahvi- } \\
\text { linden }\end{array}$ \\
\hline 13 & $\begin{array}{l}\text { Kanuni Sultan Süleyman Numune Mektebi } \\
\text { Gınâ Muallimliği }\end{array}$ & 200 & 12 Ocak 1918-31 Ağustos 1918 & Naklinden \\
\hline 14 & $\begin{array}{l}\text { Sokullu Mehmed Paşa Numune Mektebi } \\
\text { Gınâ Muallimliği }\end{array}$ & 300 & 21 Ekim 1918-14 Temmuz 1919 & Teşkilatta ibka \\
\hline 15 & $\begin{array}{c}\text { Nişantaşı İttihâd Terakki Mektebi Gınâ } \\
\text { Muallimliği }\end{array}$ & 200 & 1 Eylül 1918-31 Mart 1919 & $\begin{array}{l}\text { İkametgâhı } \\
\text { itibarıyla nakil }\end{array}$ \\
\hline 16 & $\begin{array}{c}\text { Mahmud Şevket Paşa Mektebi } \\
\text { Gınâ Muallimliği }\end{array}$ & 200 & 1 Eylül 1919-14 Temmuz 1919 & Teşkilatta ibka \\
\hline 17 & $\begin{array}{l}\text { Sokullu Mehmed Paşa Numune Mektebi } \\
\text { Gınâ Muallimliği }\end{array}$ & 300 & 15 Temmuz 1919-19 Ekim 1919 & İstifa etmiştir. \\
\hline 18 & $\begin{array}{l}\text { Selim-i Salis Numune Mektebi } \\
\text { Gınâ Muallimliği }\end{array}$ & 300 & 15 Temmuz 1919-19 Ekim 1919 & İstifa etmiştir. \\
\hline 19 & $\begin{array}{l}\text { Mahmud-1 Adli Numune Mektebi } \\
\text { Gınâ Muallimliği }\end{array}$ & 200 & 15 Temmuz 1919-19 Ekim 1919 & İstifa etmiştir. \\
\hline 20 & $\begin{array}{c}\text { Mahmud Şevket Paşa Mektebi } \\
\text { Gınâ Muallimliği }\end{array}$ & 300 & 15 Temmuz 1919-16 Aralık 1922 & Naklinden \\
\hline 21 & $\begin{array}{l}\text { Siyavuş Paşa Mektebi } \\
\text { Gınâ Muallimliği }\end{array}$ & 300 & 15 Temmuz 1919-1 Ekim 1919 & $\begin{array}{l}\text { Devamsızlığı do- } \\
\text { layısıyla müstafi } \\
\text { sayılmıştır. }\end{array}$ \\
\hline 22 & $\begin{array}{l}\text { Bayezid Numune Mektebi } \\
\text { Mûsikî Muallimliği }\end{array}$ & 300 & 17 Aralık 1922-28 Aralık 1922 & Naklinden \\
\hline 23 & $\begin{array}{c}\text { Mahmud Şevket Paşa Mektebi } \\
\text { Mûsikî Muallimliği }\end{array}$ & 300 & 29 Aralık 1922-? & - \\
\hline
\end{tabular}




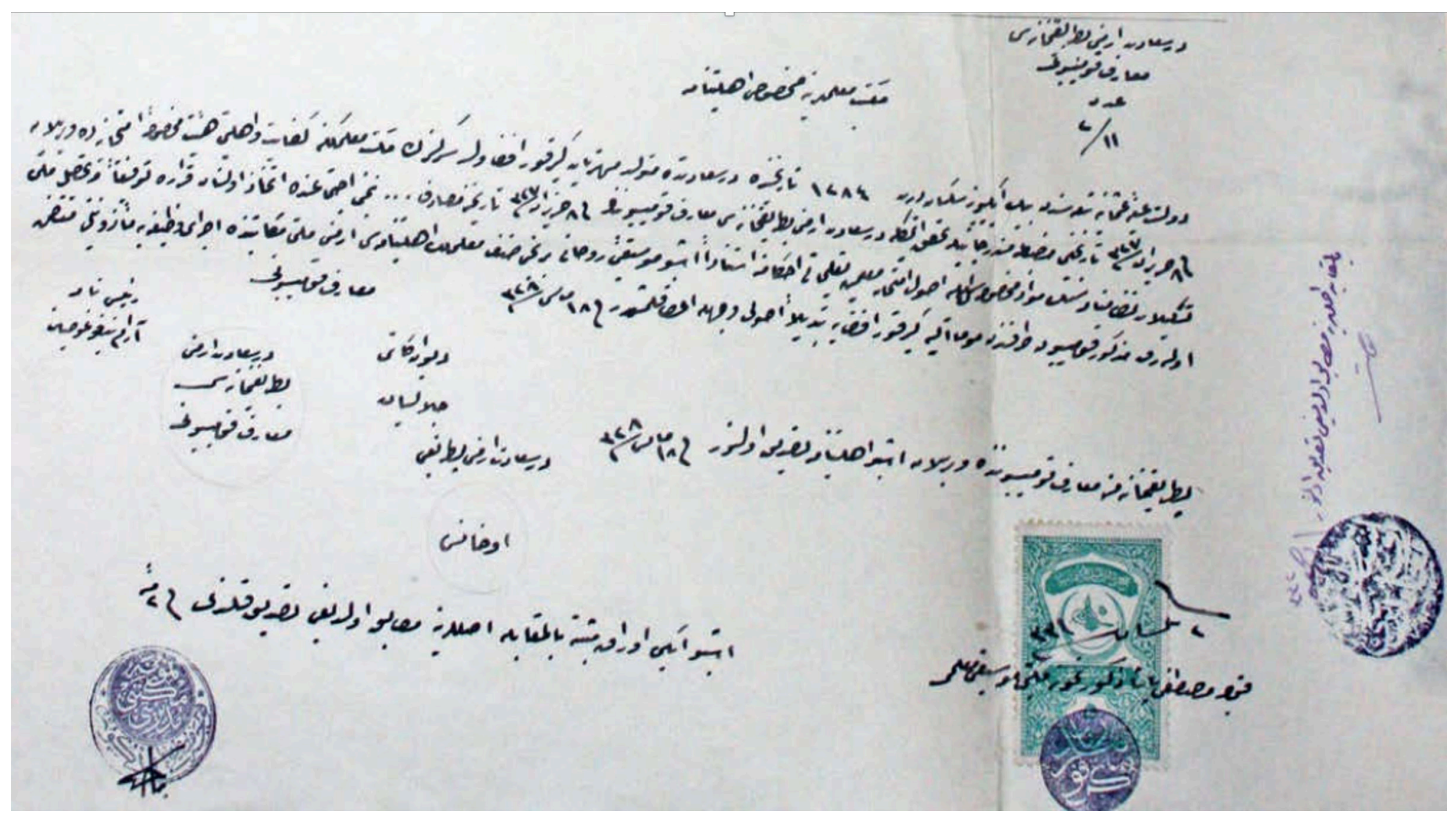

Belge 7. Kirkor Mehteryan'ın Mûsikî-i Rûhânî Birinci Sınıf Muallimlik Ehliyetnamesi (31 Mayıs 1912).

\section{Kirkor Çulhayan Efendi (1871}

\section{-1938)}

1871'de İstanbul Kumkapı'da doğmuștur. Ermeni tebaasından gümrük memuru Simon Efendi'nin oğludur. Kumkapı Ermeni Mektebi'nde okumuștur. 18 Ağustos 1911'de Dersaadet Ermeni Patrikhanesi Maarif Komisyonu kararıyla Mûsikî-i Rûhânî Birinci Sınıf Muallimlik Ehliyetnamesi verilmiștir. 18871919 yılları arasında 32 yıl Ermeni ve özel Türk Mekteplerinde gınâ ve nota muallimliklerinde bulunmuștur. Devlet hizmetine 1 Şubat 1919'da Heybeliada'daki Orhangazi Numune Mektebi gınâ ve nota muallimliğine tayiniyle girmiștir. Türkçe ve Fransızca bilmektedir. Dosyasında bu tarihten sonrasına ait kayıt bulunmamaktadır (Sicil Dosyası, No: 624). 1938'de vefat etmiștir.

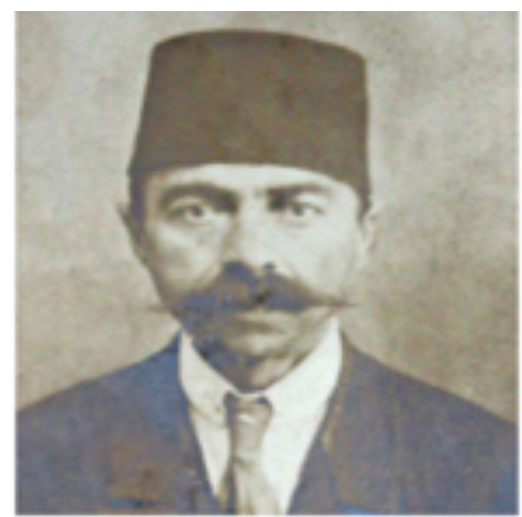

Resim 5.Kirkor Çulhayan Efendi. 


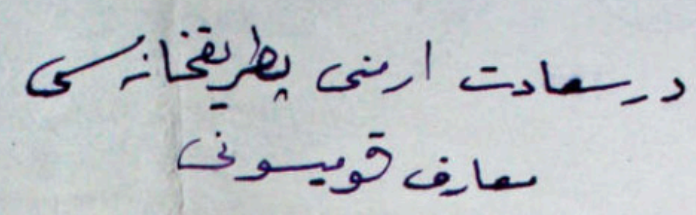

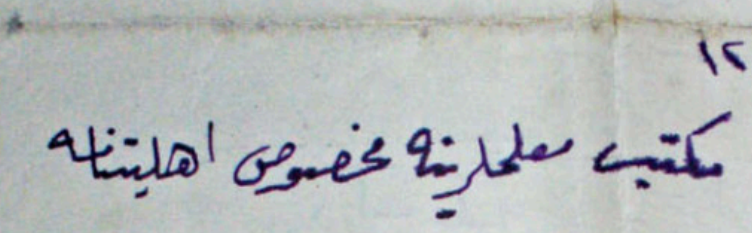

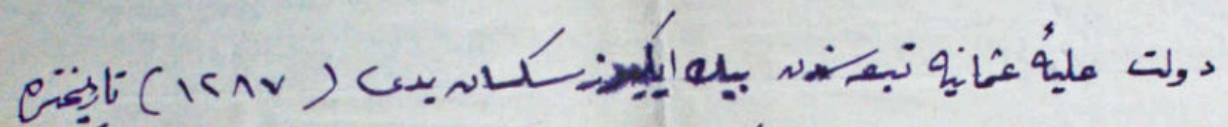

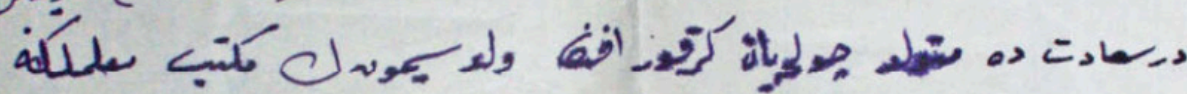

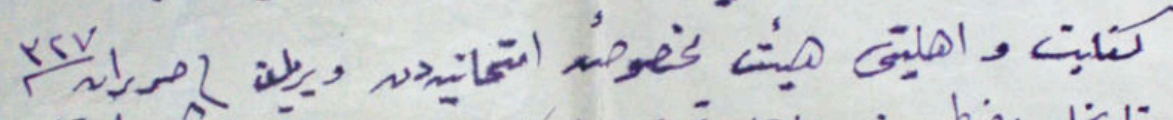

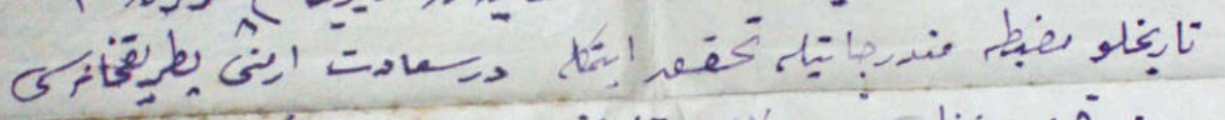

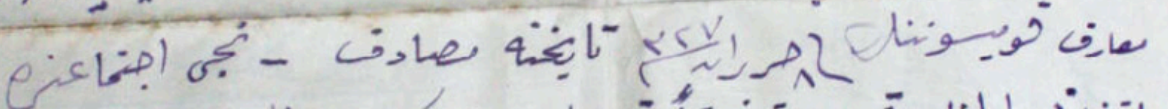

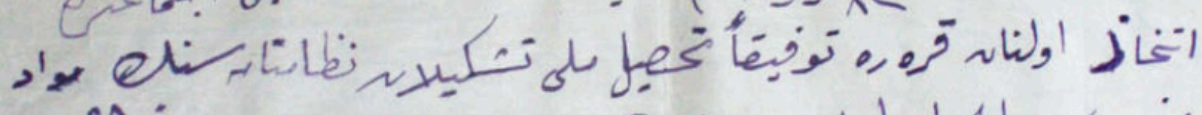

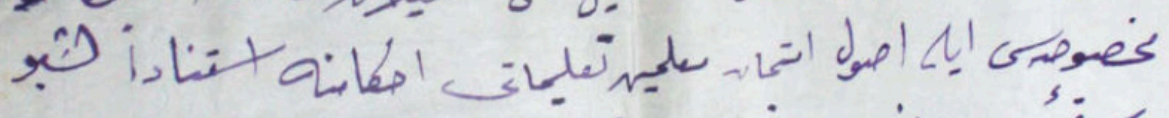

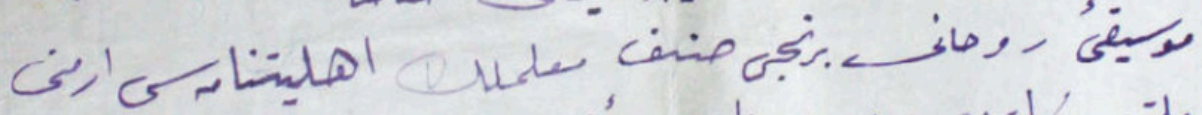

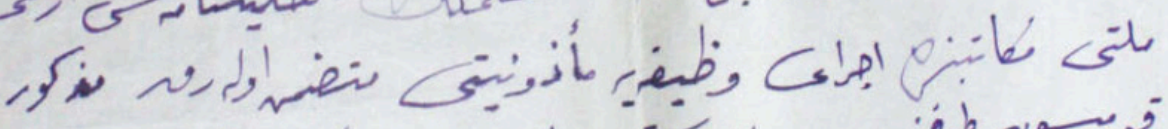

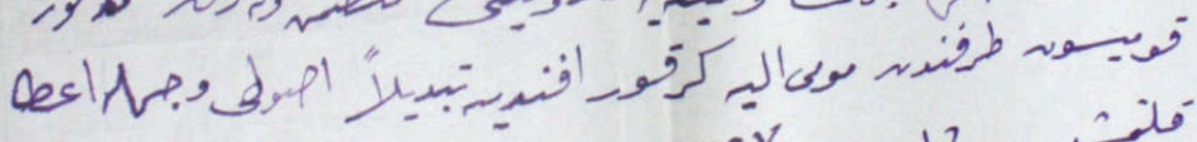

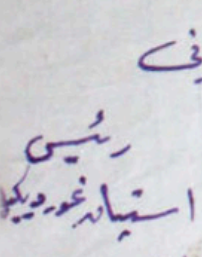

Cو rev cisto

Belge 8. Kirkor Çulhayan'ın Ermeni Patrikhanesi Maarif Komisyonu Muallimlik Ehliyetnamesi (18 Ağustos 1911) 
Tablo 11. Kirkor Çulhayan Efendi'nin çalıștığı kurumlar

\begin{tabular}{|c|c|c|c|c|}
\hline SN & Çalıştığı Mektepler ve Vazifesi & $\begin{array}{l}\text { Aldığı } \\
\text { Maaş } \\
\text { Aylık } \\
\text { Kuruş }\end{array}$ & $\begin{array}{c}\text { Göreve Başlama } \\
\text { ve Ayrılma Tarihleri }\end{array}$ & Açıklamalar \\
\hline 1 & $\begin{array}{l}\text { Büyükada’da Köprülü Mehmed } \\
\text { Paşa Zükûr ve İnas Numune } \\
\text { Mektebi Mûsikî Muallimliği }\end{array}$ & 400 & $\begin{array}{c}4 \text { Şubat 1919-14 Temmuz } \\
1919\end{array}$ & $\begin{array}{l}\text { Teşkilatta } \\
\text { ibka }\end{array}$ \\
\hline 2 & $\begin{array}{c}\text { Heybeliada'da Orhangazi } \\
\text { Numune Mektebi Mûsikî } \\
\text { Muallimliği }\end{array}$ & 400 & $\begin{array}{c}1 \text { Şubat 1919-14 Temmuz } \\
1919\end{array}$ & $\begin{array}{l}\text { Teşkilatta } \\
\text { ibka }\end{array}$ \\
\hline 3 & $\begin{array}{l}\text { Aksaray’da Şinasi Numune } \\
\text { Mektebi Mûsikî Muallimliği }\end{array}$ & 200 & $\begin{array}{c}12 \text { Aralık 1918-14 Temmuz } \\
1919\end{array}$ & $\begin{array}{l}\text { Üç mektepten } \\
\text { toplam } 1.000 \\
\text { kuruş maaş } \\
\text { almaktadır. }\end{array}$ \\
\hline 4 & $\begin{array}{l}\text { Köprülü Mehmed Paşa Numune } \\
\text { Mektebi Mûsikî Muallimliği }\end{array}$ & 400 & $\begin{array}{l}15 \text { Temmuz 1919-30 Eylül } \\
1921\end{array}$ & $\begin{array}{l}\text { Mektebin lağ- } \\
\text { vindan dolayı } \\
\text { ayrılmıştır. }\end{array}$ \\
\hline 5 & $\begin{array}{l}\text { Orhangazi Numune Mektebi } \\
\text { Mûsikî Muallimliği }\end{array}$ & 400 & $\begin{array}{c}15 \text { Temmuz 1919-26 Eylül } \\
1921\end{array}$ & $\begin{array}{l}\text { Mektebin lağ- } \\
\text { vından dolayı } \\
\text { ayrılmıştır. }\end{array}$ \\
\hline 6 & $\begin{array}{l}\text { Şinasi Numune Mektebi } \\
\text { Mûsikî Muallimliği }\end{array}$ & 300 & $\begin{array}{c}15 \text { Temmuz 1919-30 Eylül } \\
1921\end{array}$ & $\begin{array}{l}\text { Mektebin dört } \\
\text { dershaneliye } \\
\text { dönüşmesiyle } \\
\text { açıkta kalmıştır. }\end{array}$ \\
\hline 7 & $\begin{array}{l}\text { Erenköy Mektebi } \\
\text { Mûsikî Muallimliği }\end{array}$ & 400 & $\begin{array}{c}11 \text { Aralık 1920-14 Temmuz } \\
1921\end{array}$ & $\begin{array}{c}\text { Vazifesine devam } \\
\text { etmektedir. }\end{array}$ \\
\hline
\end{tabular}

3. Mûsikî Muallimeliği Ehliyetnamesi Almıș Olanlar

\section{Fakihe Hanım (1869 - ?) 1869'da İstanbul'da doğmuștur.} Tüccardan Mehmed Şükrü Efendi'nin kızıdır. İstanbul Dârülmuallimât Mektebi'nde tahsil görerek 1883'te șube muallimeliği şahadetnamesi almıștır. 25 Aralık 1915'te, Maarif Nezareti'nin emri gereğince İstanbul Dârülmuallimât Mektebi'nde teșkil edilen komisyon huzurunda yapilan piyona ve nota imtihanında, bu dersleri okutabileceğine ilișkin ehliyetname almıștır. 16 Ekim 1923'te, müsabakada bașarılı olamadığından açıkta kalmıștır. 20 Şubat 1928 'de 42 lira ikramiye tahsis edilerek görevine son verilmiștir. Hizmet süresi 11 sene 7 ay 23 gün olup 29 sene 6 ay 25 gün açıkta kalmıștır (Sicil Dosyası, No: 522).

\section{Hatice Leman Hanım (1899-?)} 1899'da İstanbul'da doğmuștur. İbrahim Efendi'nin kızıdır. İbtidâi ve rüșdi tahsilini altı dershaneli Bayezid İnas Numune Mektebi'nde tamamlayarak aliyyü'l-a'lâ derecede şahadetname ile mezun olmuștur. 1919'da İstanbul Vilayeti Tedrisat-1 ibtidâiye Meclisi huzurunda yapilan imtihan neticesinde, mekâtib-i ibtidâiye mûsikî muallimeliği ehliyetnamesi almıștır. 18 Aralık 1922 tarihinde, derslere gelmemesinden ve devamsızlığından dolayı görevine son 
Tablo 12. Fakihe Hanım'ın çalıștığı kurumlar

\begin{tabular}{|c|c|c|c|c|}
\hline SN & Çalıştığı Mektepler ve Vazifesi & $\begin{array}{l}\text { Aldığı } \\
\text { Maaş } \\
\text { Aylık } \\
\text { Kuruş }\end{array}$ & $\begin{array}{c}\text { Göreve Başlama } \\
\text { ve Ayrılma Tarihleri }\end{array}$ & Açıklamalar \\
\hline 1 & $\begin{array}{l}\text { İstanbul Dârülmuallimâtı } \\
\text { Şube Muallime-i saliseliği }\end{array}$ & 250 & 23 Eylül 1883-12 Ocak 1884 & Naklinden \\
\hline 2 & $\begin{array}{c}\text { Dârülmuallimât } \\
\text { Piyano Muallimeliği }\end{array}$ & 100 & 1 Şubat 1884-3 Eylül 1884 & İlave \\
\hline 3 & $\begin{array}{l}\text { Dârülmuallimât Şube Muallime-i } \\
\text { saliseliği ve Piyano Muallimeliği }\end{array}$ & 380 & 4 Eylül 1884-19 Ocak 1886 & İstifa etmiştir. \\
\hline 4 & $\begin{array}{l}\text { İstanbul Dârülmuallimâtı } \\
\text { Piyano Muallimeliği }\end{array}$ & 150 & 20 Ocak 1886-29 Nisan 1887 & İstifa etmiştir. \\
\hline \multicolumn{5}{|c|}{ Piyano dersinin kaldırılması üzerine vazifesinin lağvından 28 sene 10 ay 23 gün açıkta kalmıştır. } \\
\hline 5 & $\begin{array}{c}\text { Cevri Usta İnas Mektebi } \\
\text { Gınâ Muallimeliği } \\
\end{array}$ & 200 & 27 Mart 1916-10 Haziran 1917 & Ders ilavesi \\
\hline 6 & $\begin{array}{c}\text { Cevri Usta ve Kanlıca Mektepleri } \\
\text { Gınâ Muallimeliği }\end{array}$ & 400 & $\begin{array}{c}11 \text { Haziran 1917-14 Temmuz } \\
1919\end{array}$ & $\begin{array}{l}\text { Teşkilatta } \\
\text { ibka }\end{array}$ \\
\hline 6 & $\begin{array}{c}\text { Davudpaşa ve Kasımpaşa } \\
\text { Mektepleri Gınâ Muallimeliği }\end{array}$ & 600 & 15 Temmuz 1919-11 Ocak 1920 & Ders ilavesi \\
\hline 7 & $\begin{array}{c}\text { Davudpaşa, Kasımpaşa ve } \\
\text { Hatice Sultan Mektepleri } \\
\text { Gınâ Muallimeliği } \\
\end{array}$ & 900 & 12 Ocak 1920-12 Nisan 1920 & $\begin{array}{l}\text { 300’er kuruş } \\
\text { ücret almak- } \\
\text { tadır. }\end{array}$ \\
\hline 8 & $\begin{array}{l}\text { Davudpaşa, Kasımpaşa ve } \\
\text { Fatih Mektepleri Gınâ Muallimeliği }\end{array}$ & 900 & 15 Nisan 1920-31 Ocak 1921 & $\begin{array}{l}\text { Fatih Mek- } \\
\text { tebi’nden } \\
\text { ayrılmıştır. }\end{array}$ \\
\hline 9 & $\begin{array}{c}\text { Davudpaşa ve Kasımpaşa } \\
\text { Mektepleri Gınâ Muallimeliği }\end{array}$ & 600 & 1 Şubat 1921-8 Şubat 1921 & Ders ilavesi \\
\hline 10 & $\begin{array}{l}\text { Davudpaşa, Kasımpaşa ve } \\
\text { Murad-1 Hâmis Mektepleri } \\
\text { Gınâ Muallimeliği }\end{array}$ & 900 & 9 Şubat 1921-30 Eylül 1921 & $\begin{array}{l}\text { Vazifesinin } \\
\text { lağvından } \\
\text { dolayı } \\
7 \text { ay açıkta } \\
\text { kalmıştır. }\end{array}$ \\
\hline 11 & $\begin{array}{l}\text { Kasımpaşa ve Nilüfer Hatun } \\
\text { Mektepleri Gınâ Muallimeliği }\end{array}$ & 600 & 1 Mayıs 1922-16 Ekim 1923 & Açıkta \\
\hline
\end{tabular}

Tablo 13. Hatice Leman Hanım'ın çalıștığı kurumlar

\begin{tabular}{|c|c|c|c|c|}
\hline SN & $\begin{array}{c}\text { Çalıştığı Mektepler ve } \\
\text { Vazifesi }\end{array}$ & $\begin{array}{c}\text { Aldığı Maaş } \\
\text { Aylık Kuruş }\end{array}$ & $\begin{array}{c}\text { Göreve Başlama } \\
\text { ve Ayrılma Tarihleri }\end{array}$ & Açılamalar \\
\hline $\mathbf{1}$ & $\begin{array}{c}\text { Çelebi Sultan Mehmed } \\
\text { Mektebi Mûsikî } \\
\text { Muallimeliği }\end{array}$ & 300 & 10 Eylül 1919-15 Eylül 1921 & $\begin{array}{c}\text { Derslere munta- } \\
\text { zam olarak devam } \\
\text { etmediğinden } \\
\text { ihtar almıştır. }\end{array}$ \\
\hline $\mathbf{2}$ & $\begin{array}{c}\text { Hatice Sultan Mektebi } \\
\text { Mûsikî Muallimeliği }\end{array}$ & 300 & 24 Nisan 1920-15 Eylül 1921 & Azledilmiştir. \\
\hline $\mathbf{3}$ & $\begin{array}{c}\text { Eyüb İnas Numune Mektebi } \\
\text { Gı̂â Muallimeliği }\end{array}$ & 300 & 20 Ekim 1921-18 Aralık 1922 & \\
\hline
\end{tabular}


verilmiștir (Sicil Dosyası, No: 649).

\section{Kerime Hanım (1878 - ?)}

1878'de Midilli Adası'nda doğmuștur. Çapanzade Nebih Bey'in kızıdır. 17 Ocak 1923'te, Dârülmuallimât-1 Âliye'de olușturulan komisyon huzurunda yapılan imtihanda, tali mekteplerde mûsikî muallimeliği yapmaya liyakati olduğuna dair belge almıștır. 13 Eylül 1925'te, dosyası Vekâlet Sicil Müdüriyeti'ne gönderilmiștir (Sicil Dosyası, No: 61).

\section{Meliha Fatma Hanım (1904- ?)} 1904'te Gelibolu'da doğmuștur. Şehremaneti Tahrirat Kâtibi HacıAbdullah Kazım Efendi'nin kızıdır. Gelibolu'da Sarı Mektep namındaki Mekteb-i İbtidâi'nin 3. sınıfına kadar okumuşsa da tasdikname almaksızın İstanbul'a hicret etmek durumunda kalmıștır. Burada bir yıl Süleymaniye İnas Numune Mektebi'nde, üç yıl Bezmiâlem İnas Sultanîsi'nin İbtidâi kısmında, bir ay Nilüfer HatunInas Numune Mektebi'nde, altı ay da Kıztașı Inas Numune Mektebi'nde okumuş ve nihayet, 8 Haziran 1920'de Fatih Saraçhanebașı'ndaki Çelebi Sultan Mehmed İnas Numune Mektebi'nden aliyyü'l-a'lâ dereceli tasdikname ile mezun olmuștur. Aldığı tasdiknameleri naklen gittiğ́i mekteplere verdiğinden asılları elinde bulunmamaktadır. Bir yandan da, Sultan Mahmud Han-1 Sani İnas Numune Mektebi Gınâ muallimi Kevser Hanım'dan özel Keman dersleri almıștır. 30 Ekim 1921'de Maarif-i Umumiye Nezareti Mûsikî Encümeni huzurunda yapılan imtihanda, aliyyü'la'lâ derecede mûsikî muallimeliği ehliyetnamesi almıștır. Dosyasında 5 Kasım 1921 tarihinden sonrasına ilișkin kayıt bulunmamaktadır (Sicil Dosyası, No: 853).

Tablo 14. Kerime Hanım'ın çalıștığı kurumlar

\begin{tabular}{|c|c|c|c|c|}
\hline SN & Çalıştığı Mektepler ve Vazifesi & $\begin{array}{c}\text { Aldığı Maaş } \\
\text { Aylık Kuruş }\end{array}$ & $\begin{array}{c}\text { Göreve Başlama } \\
\text { ve Ayrılma Tarihleri }\end{array}$ & Açıklamalar \\
\hline $\mathbf{1}$ & $\begin{array}{c}\text { Refet Kadın Sultan İnas Numune } \\
\text { Mektebi Mûsikî Muallimeliği }\end{array}$ & 300 & 17 Şubat 1923-15 Ekim \\
1923 & $\begin{array}{c}\text { Teşkilatta nakil } \\
\text { edilmiştir. }\end{array}$ \\
\hline $\mathbf{2}$ & $\begin{array}{c}\text { Prenses Fatma Hanım, } \\
\text { Ahmed Midhat Efendi ve } \\
\begin{array}{c}\text { Süleyman Kaya Alp Mektepleri } \\
\text { Mûsikî Muallimeliği }\end{array}\end{array}$ & $600 / 700$ & 16 Ekim 1923-30 Eylül & $\begin{array}{c}\text { Hasbe’t-teş- } \\
\text { kilat }\end{array}$ \\
\hline $\mathbf{3}$ & $\begin{array}{c}\text { Mihrimah Sultan Mektebi } \\
\text { Mûsikî Muallimeliği }\end{array}$ & 700 & 1 Ekim 1924- & Başlamamıştır. \\
\hline
\end{tabular}

Tablo 15. Meliha Fatma Hanım'ın çalıștığı kurumlar

\begin{tabular}{|c|c|c|c|c|}
\hline SN & Çalıştığı Mektepler ve Vazifesi & $\begin{array}{c}\text { Aldığı Maaş } \\
\text { Aylık Kuruş }\end{array}$ & $\begin{array}{c}\text { Göreve Başlama } \\
\text { ve Ayrılma Tarihleri }\end{array}$ & Açıklamalar \\
\hline $\mathbf{1}$ & $\begin{array}{c}\text { Kıztaşı'nda Sultan Abdülaziz } \\
\text { Han Numune Mektebi } \\
\text { Gınâ Muallimeliği }\end{array}$ & 300 & 5 Kasım 1921- & $\begin{array}{c}\text { Devam etmek- } \\
\text { tedir. }\end{array}$ \\
\hline
\end{tabular}




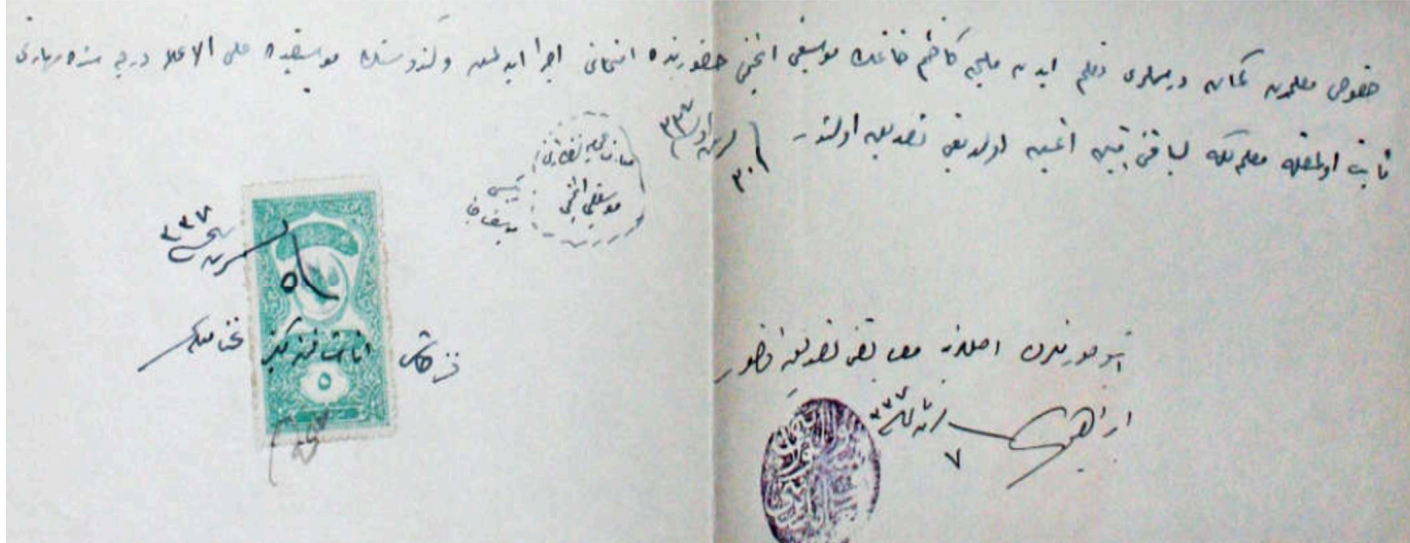

Belge 9. Meliha Hanım'ın Maarif-i Umumiye Nezareti Mûsikî Encümeni Ehliyetnamesi (30 Ekim 1921).

\section{Fatma Zahide Hanım (14 Ocak} 1892 - ?)

14 Ocak 1892'de İstanbul'da doğmuștur. Beșiktaș Sinan Pașa Camii İmam-Hatibi $\mathrm{HaCl}$ Tahir Efendi'nin kızıdır. İbtidâi ve rüșdi tahsilini Beșiktaş'taki özel Hamidiye Mektebi'nde tamamlayarak șahadetname almıștır. 1917'de Dârülelhan'ınFasl-ı Mûsikîkısmına kayıtla 19 Ocak 1919'da tasdikname almıștır. İstanbul Vilayeti Tedrisat-1 İbtidâiye Meclisi huzurunda yapılan imtihan neticesinde, mekâtib-i ibtidâiyede mûsikî dersleri verebileceğine dair ehliyetname almıştır. Kemençe, Piyano ve Keman çalabilmektedir. 30 Eylül 1931'de, devlet imtihanında bașarılı olamadığından görevine son verilmiștir. İstanbul'daki hizmet süresi 12 sene 7 ay 16 gündür (Sicil Dosyası, No: 611).

Tablo 16. Fatma Zahide Hanım'ın çalıștığı kurumlar

\begin{tabular}{|c|c|c|c|c|}
\hline $\mathbf{S N}$ & Çalıștığı Mektepler ve Vazifesi & $\begin{array}{l}\text { Aldığı Maaş } \\
\text { Aylık Kuruş }\end{array}$ & $\begin{array}{c}\text { Göreve Başlama } \\
\text { ve Ayrılma Tarihleri }\end{array}$ & Açıklamalar \\
\hline 1 & $\begin{array}{l}\text { Mihrimah Sultan Mektebi } \\
\text { Gınâ Muallimeliği }\end{array}$ & 300 & 23 Nisan 1919-14 Temmuz 1919 & $\begin{array}{l}\text { Teşkilatta } \\
\text { ibka }\end{array}$ \\
\hline 2 & $\begin{array}{l}\text { Aynışah Sultan Mektebi } \\
\text { Gınâ Muallimeliği }\end{array}$ & 300 & 10 Haziran 1919-24 Eylül 1921 & $\begin{array}{l}\text { Mektep kadrosu- } \\
\text { nun tebdilinden } \\
\text { açıkta kalmıştır. }\end{array}$ \\
\hline 3 & $\begin{array}{l}\text { Mihrimah Sultan Mektebi } \\
\text { Gınâ Muallimeliği }\end{array}$ & 300 & 15 Temmuz 1919-8 Aralık 1922 & \multirow{2}{*}{$\begin{array}{l}\text { Ahval-i sıhhi- } \\
\text { yesinden dolay1 } \\
\text { istifa etmiştir. }\end{array}$} \\
\hline 4 & $\begin{array}{c}\text { Prenses Fatma Hanım Mektebi } \\
\text { Gınâ Muallimeliği }\end{array}$ & 300 & 26 Ekim 1921-8 Aralık 1922 & \\
\hline 5 & $\begin{array}{c}\text { Büyük Esma Sultan Mektebi } \\
\text { Gınâ Muallimeliği }\end{array}$ & 300 & 19 Kasım 1921-15 Ekim 1923 & Hasbe't-teşkilat \\
\hline 6 & $\begin{array}{l}\text { Mihrimah Sultan ve Nilüfer Hatun } \\
\text { Mektepleri Gınâ Muallimeliği }\end{array}$ & 600 & 16 Ekim 1923-30 Eylül 1924 & $\begin{array}{l}\text { Teşkilatta } \\
\text { ibka }\end{array}$ \\
\hline 7 & $\begin{array}{l}\text { Nilüfer Hatun Mektebi } \\
\text { Gınâ Muallimeliği }\end{array}$ & $600 / 700$ & 1 Ekim 1924-21 Mart 1926 & $\begin{array}{l}\text { Maaşına zam } \\
\text { almıştır. }\end{array}$ \\
\hline 8 & Beyoğlu 15. Mektep Muallimeliği & 1620 & 22 Mart 1926-30 Eylül 1931 & $\begin{array}{l}\text { Devlet imtiha- } \\
\text { nında başarılı } \\
\text { olamadığından }\end{array}$ \\
\hline
\end{tabular}




\section{Aliye Sabiha OSMAY (1886 - ?)} 1886'da Selanik'te doğmuștur. Tahlisiye muhasebecisi Osman Tevfik Bey'in kızıdır. İbtidâi tahsilini Selanik'te özel Feyziye Mektebi'nde tamamlayarak 14 Temmuz 1902'de aliyyü'l-a'lâ derecede șahadetname almıștır. Tali tahsilini ise Selanik Alyans İsrailit Mektebi ile özel hocalarda tamamlamıștır. Selanik Alyans İsrailit Mektebi'nde öğrenci olduğu 18 Ocak 1904 - 13 Mayıs 1905 arasında bir yandan da 500 kuruş maaşla Türkçe muallimeliği yapmıștır. 13 Mayıs 1905 'te muallimelikten istifa ederek İstanbul'a gelmiștir. Mektepten almış olduğu tasdiknameyi zayi etmiștir. 1 Ekim 1917'den itibaren İstanbul Ticaret Mekteb-i Âliyesi kısm- evveline bağıı İnas Șubesi'ne devamla 13 Temmuz 1918'de aliyyü'l-a'lâ derecede tasdikname almıștır. 11 Eylül 1926'da İstanbul Vilayeti Tedrisat-1 İbtidâiye Meclisi huzurunda yapılan imtihan neticesinde mekâtib-i ibtidâiye mûsikî muallimeliği ehliyetnamesi almıștır. Fransızca bilmekte ve Piyano çalmaktadır. 30

Tablo 17. Aliye Sabiha Osmay'ın çalıștığı kurumlar

Eylül 1950'de emekliye ayrılmıștır (Sicil Dosyası, No: 505).

\section{Mûsikî Eğitimi Almıș Olanlar} 1. Emine Muzaffer Hanım (1887 - ?)

1887'de İstanbul'da doğmuștur. Mustafa Vehbi Bey'in kızıdır. Üsküdar Atlamatașı İnas Rüşdiyesi'nin son sınıfına kadar okumuşsa da evlilik sebebiyle sahadetname alamamıștır. Orta tahsilini özel derslerle tamamlamıștır. Dârülelhan ve konservatuarda eski ve yeni usul mûsikî eğitimi almıștır. Piyano ve keman çalabilmektedir. Dosyasında 22 Mart 1926 tarihinden sonrasıyla ilgili kayıt bulunmamaktadır (Sicil Dosyası, No: 990).

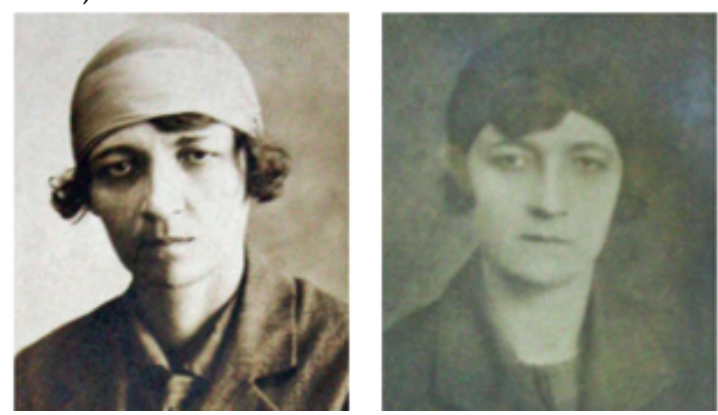

Resim 7. Emine Muzaffer Hanım.

\begin{tabular}{|c|c|c|c|c|}
\hline SN & Çalıştığı Mektepler ve Vazifesi & $\begin{array}{l}\text { Aldığı Maaş } \\
\text { Aylık Kuruş }\end{array}$ & $\begin{array}{c}\text { Göreve Başlama } \\
\text { ve Ayrılma Tarihleri }\end{array}$ & $\begin{array}{l}\text { Açıklama- } \\
\text { lar }\end{array}$ \\
\hline 1 & $\begin{array}{c}\text { Selanik Alyans İsrailit Mektebi } \\
\text { Türkçe Muallimeliği }\end{array}$ & 500 & 18 Ocak 1904-13 Mayıs 1905 & $\begin{array}{l}\text { İstifa } \\
\text { etmiştir. }\end{array}$ \\
\hline 2 & $\begin{array}{l}\text { İstanbul Fatih İnas Numune } \\
\text { Mektebi Türkçe Muallimeliği }\end{array}$ & 600 & 14 Ekim 1915-18 Eylül 1917 & Terfi \\
\hline 3 & $\begin{array}{l}\text { Fatih İnas Numune Mektebi } \\
\text { Fransızca Muallimeliği }\end{array}$ & $800 / 1.000$ & 19 Eylül 1917-30 Eylül 1924 & Naklen \\
\hline 4 & $\begin{array}{c}\text { Esma Kaya Sultan Mektebi } \\
\text { Muallimeliği }\end{array}$ & $1.000 / 1.740$ & 1 Ekim 1924-31 Mayıs 1929 & Zam \\
\hline 5 & İstanbul 2. Mektep Muallimeliği & $2.001 / 2.000$ & 1 Haziran 1929-30 Eylül 1932 & Naklinden \\
\hline 6 & Kadıköy 41. Mektep Muallimeliği & $2.000 / 2.200$ & 1 Ekim 1932-31 Ağustos 1939 & Zam \\
\hline 7 & Kadıköy 41. Okul Öğretmenliği & 2.500 & 1 Eylül 1939-30 Nisan 1949 & $\begin{array}{c}\text { Okul adının } \\
\text { değişme- } \\
\text { sinden }\end{array}$ \\
\hline 8 & $\begin{array}{c}\text { Kadıköy Bahariye Okulu } \\
\text { Öğretmenliği }\end{array}$ & 5.000 & 1 Mayıs 1949-30 Eylül 1950 & $\begin{array}{l}\text { Emekliye } \\
\text { sevk }\end{array}$ \\
\hline
\end{tabular}


Tablo 18. Emine Muzaffer Hanım'ın çalıștığı kurumlar

\begin{tabular}{|c|c|c|c|c|}
\hline SN & Çalıştığı Mektepler ve Vazifesi & $\begin{array}{c}\text { Aldığı } \\
\text { Maaş } \\
\text { Aylık } \\
\text { Kuruş }\end{array}$ & $\begin{array}{c}\text { Göreve Başlama } \\
\text { ve Ayrılma Tarihleri }\end{array}$ & Açıklamalar \\
\hline $\mathbf{1}$ & $\begin{array}{c}\text { Kasımpaşa İnas Numune Mektebi } \\
\text { Mürebbiyeliği }\end{array}$ & 600 & 3 Nisan 1915-20 Kasım & Naklinden \\
\hline $\mathbf{2}$ & $\begin{array}{c}\text { Sultantepe Ana Mektebi } \\
\text { Muallimeliği }\end{array}$ & 600 & 21 Kasım 1916-28 Şubat & Naklen \\
\hline $\mathbf{3}$ & $\begin{array}{c}\text { Üsküdar'da Mal Hatun Innas } \\
\text { Numune Mektebi Gınâ Muallimeliği }\end{array}$ & 300 & 1 Ekim 1918-15 Ekim 1923 & Hasbe’t-teşkilat \\
\hline $\mathbf{4}$ & $\begin{array}{c}\text { Erenköy Sultanîsi } \\
\text { Gınâ Muallimeliği }\end{array}$ & 500 & 9 Mart 1918-15 Ekim 1923 & Teşkilatta ibka \\
\hline $\mathbf{5}$ & $\begin{array}{c}\text { Mal Hatun, Refet Kadın Sultan ve } \\
\text { Mahfiruz Sultan İnas Numune } \\
\text { Mektepleri Gınâ Muallimeliği }\end{array}$ & 600 & 16 Ekim 1923-30 Eylül & Hasbe’t-teşkilat \\
\hline $\mathbf{6}$ & $\begin{array}{c}\text { Mal Hatun İnas Numune Mektebi } \\
\text { Gınâ Muallimeliği }\end{array}$ & $600 / 700$ & 1 Ekim 1924-21 Mart 1926 & Maaşına \\
\hline $\mathbf{7}$ & $\begin{array}{c}\text { Üsküdar 20. İlk Kız Mektebi } \\
\text { Mûsikî Muallimeliği }\end{array}$ & 1.740 & 22 Mart 1926- & - \\
\hline
\end{tabular}

\section{Azize Hanım (1881 - ?)}

1881'de İstanbul'da doğmuștur. Merhum İbrahim Cevad Bey'in kızıdır. Dârülelhan çıkışlıdır. Dosyasında 1 Ekim 1924 tarihinden sonrasina dair kayıt bulunmamaktadır (Sicil Dosyası, No: 787).

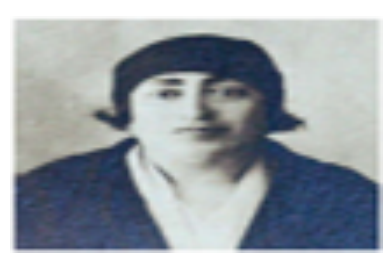

Resim 8. Azize Hanım.

Tablo 19. Azize Hanım'ın çalıștığı kurumlar

\begin{tabular}{|c|c|c|c|c|}
\hline SN & Çalıştığı Mektepler ve Vazifesi & $\begin{array}{l}\text { Aldığı } \\
\text { Maaş } \\
\text { Aylık } \\
\text { Kuruş }\end{array}$ & $\begin{array}{c}\text { Göreve Başlama } \\
\text { ve Ayrılma Tarihleri }\end{array}$ & Açıklamalar \\
\hline 1 & $\begin{array}{l}\text { Moda Numune Mektebi } \\
\text { Gınâ Muallimeliği }\end{array}$ & 300 & 12 Ocak 1921-7 Kasım 1921 & Azlinden \\
\hline 2 & $\begin{array}{c}\text { Köprülü Mehmed Paşa Mektebi } \\
\text { Gınâ Muallimeliği }\end{array}$ & 300 & 1 Ekim 1922-16 Ekim 1923 & Nakil \\
\hline 3 & Orhangazi Mektebi Gınâ Muallimeliği & 300 & 1 Ekim 1922-16 Ekim 1923 & Nakil \\
\hline 4 & $\begin{array}{c}\text { Şehid Muhtar Bey, Mahmud-1 Sani ve } \\
\text { Kasımpaşa Mektepleri } \\
\text { Gınâ Muallimeliği }\end{array}$ & 600 & 16 Ekim 1923-1 Ekim 1924 & $\begin{array}{l}\text { Teşkilatta } \\
\text { ibka }\end{array}$ \\
\hline 5 & Kasımpaşa Mektebi Gınâ Muallimeliği & 600 & 1 Ekim 1924- & - \\
\hline
\end{tabular}


3. Mehmed Necati Efendi (1898 - ?) 1898 'de İstanbul'da doğmuștur. Sütlüce Numune Mektebi muallimlerinden İsmail Hakkı Efendi'nin oğludur. Nișancı Rami Mustafa Pașa Mektebi'nde hafızlık eğitimi almıștır. 23 Ağustos 1915'te Sütlüce Numune Mekteb-i İbtidâisi'nden aliyyü'l-a'lâ derecede șahadetname ile mezun olmuş ve Darülhilafeti'l-Aliyye Medresesi'nin 3. sınifina kadar ders görmüștür. Seferberlikte silah altına alınarak talimgâha sevk edilmiş ve bașçavuşluğa kadar terfi ettikten sonra terhis olunmuștur. Zekâi Dedezade'den Mûsikîye aşina olduğuna dair tasdiknamesi vardır. 15 Ekim 1923'te, müsabaka imtihanına girmediğinden açıkta kalmıștır (Sicil Dosyası, No: 739). suretiyle tamamlamıștır. Bu arada, dayısı Tanburi Cemil Bey'den de mûsikî eğitimi almıştır. Hiçbir mektepten şahadetname ve tasdiknamesi yoktur. 1903'te Maliye Nezareti Muhasebe-i Umumiye Merkez Kalemi'ne girmiș ise de mûsikî eğitimi için memuriyetten ayrılmıștır. 15 Şubat 1905'te rütbe-i salise ile taltif olunmuștur. 1910-11 yılları arasında Kadıköy'deki özel Terakki Mektebi'nde, 1913'te de Kadıköy İttihâd-ı Osmanî Mektebi'nde mûsikî muallimliği yapmıștır. Fransızcaya așinalığı vardır. Dosyasında 1 Şubat 1923 tarihinden sonrasına ilișkin kayıt bulunmamaktadır (Sicil Dosyası, No: 616). 20 Temmuz 1923'te İstanbul'da akciğer vereminden vefat etmiștir (2017, Eylül 1).

Tablo 20. Mehmet Necati Efendi'nin çalıștığı kurumlar

\begin{tabular}{|c|c|c|c|c|}
\hline SN & Çalıştığı Mektepler ve Vazifesi & $\begin{array}{l}\text { Aldığı Maaş } \\
\text { Aylık Kuruş }\end{array}$ & $\begin{array}{c}\text { Göreve Başlama } \\
\text { ve Ayrılma Tarihleri }\end{array}$ & Açıklamalar \\
\hline 1 & $\begin{array}{l}\text { Erenköy Numune Mektebi } \\
\text { Mûsikî Muallimliği }\end{array}$ & 300 & $\begin{array}{l}25 \text { Mart 1920-24 Ekim } \\
1920\end{array}$ & $\begin{array}{l}\text { Yaş itibariyle } \\
\text { nakil }\end{array}$ \\
\hline 2 & $\begin{array}{l}\text { Reşadiye Numune Mektebi } \\
\text { Mûsikî Muallimliği }\end{array}$ & 300 & $\begin{array}{c}25 \text { Ekim 1920-22 Mart } \\
1921\end{array}$ & Ders ilavesinden \\
\hline 3 & $\begin{array}{l}\text { Reşadiye ve Hoca İshak Efendi } \\
\text { Mektepleri Mûsikî Muallimliği }\end{array}$ & 600 & $\begin{array}{c}23 \text { Mart 1921-6 Haziran } \\
1923\end{array}$ & $\begin{array}{l}\text { Reşadiye Mek- } \\
\text { tebi’nden istifa } \\
\text { etmiştir. }\end{array}$ \\
\hline 4 & $\begin{array}{l}\text { Hoca İshak Efendi } \\
\text { Mûsikî Muallimliği }\end{array}$ & 300 & $\begin{array}{c}7 \text { Haziran 1923-15 Ekim } \\
1923\end{array}$ & Açıkta kalmıştır. \\
\hline
\end{tabular}

4. Arif Hikmet Bey (1884 - 20

Temmuz 1923)

1884'te İstanbul'da doğmuştur. İstanbul pâyeli Aydın merkez sabık kadısı ve Edirne naibi Abdurrahman Efendi'nin oğludur. Annesi, Tanburi Cemil Bey'in ablası Beyhan Hanım'dır. ibtidâi tahsilini özel Darüttahsil Mektebi'nde tamamlamıștır. 1897'de Mekteb-i Sultanî'ye (Galatasaray Lisesi) kayıtla 3. sınıfa kadar okumuşsa da sağlık sorunları dolayısıyla mektepten ayrılmak zorunda kalmıștır. Tahsilini özel dersler almak

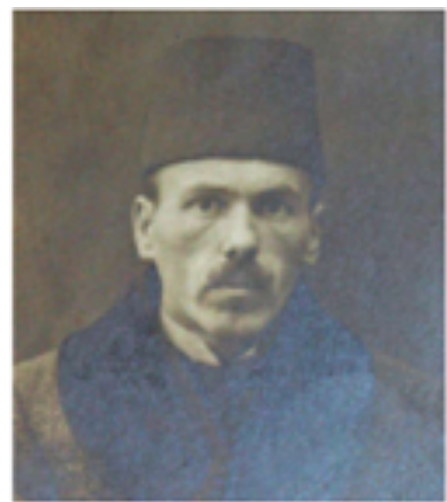

Resim 9. Arif Hikmet Bey. 
Tablo 21. Arif Hikmet Bey’in çalıștığı kurumlar

\begin{tabular}{|c|c|c|c|c|}
\hline SN & Çalıştığı Mektepler ve Vazifesi & $\begin{array}{l}\text { Aldığı Maaş } \\
\text { Aylık Kuruş }\end{array}$ & $\begin{array}{c}\text { Göreve Başlama } \\
\text { ve Ayrılma Tarihleri }\end{array}$ & Açıklamalar \\
\hline 1 & $\begin{array}{c}\text { Beylerbeyi Bostancıbaşı } \\
\text { Abdullah Ağa Mûsikî Muallimi }\end{array}$ & 200 & $\begin{array}{l}1 \text { Şubat 1919-1 Ağustos } \\
1919 \\
\end{array}$ & Naklinden \\
\hline 2 & $\begin{array}{c}\text { Süleymaniye Camii sırasında } \\
\text { Kanuni Sultan Süleyman Mektebi } \\
\text { Mûsikî Muallimi }\end{array}$ & 200 & $\begin{array}{c}18 \text { Ocak 1919-1 Ağustos } \\
1919\end{array}$ & $\begin{array}{l}\text { Teşkilatta } \\
\text { ibka }\end{array}$ \\
\hline 3 & $\begin{array}{l}\text { Kartal Mektebi } \\
\text { Mûsikî Muallimi }\end{array}$ & $200 / 300$ & $\begin{array}{c}8 \text { Nisan 1919-6 Şubat } \\
1921\end{array}$ & $\begin{array}{l}\text { Ahval-i sıhhiye- } \\
\text { sine mebni istifa } \\
\text { etmiştir. }\end{array}$ \\
\hline 4 & $\begin{array}{l}\text { Büyük Reşid Paşa Mektebi } \\
\text { Mûsikî Muallimi }\end{array}$ & 300 & - & $\begin{array}{c}\text { Başlamamıştır. } \\
\text { Osmangazi Nu- } \\
\text { mune Mekte- } \\
\text { bi'ne naklen }\end{array}$ \\
\hline 5 & $\begin{array}{l}\text { Aziziye Mektebi } \\
\text { Mûsikî Muallimi }\end{array}$ & 300 & $\begin{array}{l}15 \text { Ağustos 1919-30 } \\
\text { Kasım } 1919\end{array}$ & $\begin{array}{l}\text { Mektebin Maarif } \\
\text { Nezareti'ne } \\
\text { devrinden dolayı } \\
\text { ayrılmıştır. }\end{array}$ \\
\hline 6 & $\begin{array}{c}\text { Kanuni Sultan Süleyman Mektebi } \\
\text { Mûsikî Muallimi }\end{array}$ & 300 & $\begin{array}{l}1 \text { Ağustos 1919-1 Ocak } \\
1923\end{array}$ & $\begin{array}{c}\text { Mektebin Baye- } \\
\text { zid'e naklinden } \\
\text { dolayı ayrılmış- } \\
\text { tır. }\end{array}$ \\
\hline 7 & $\begin{array}{l}\text { Ahmed Midhat Efendi Mektebi } \\
\text { Mûsikî Muallimi }\end{array}$ & 300 & - & $\begin{array}{l}\text { Başlamamıştır. } \\
\text { Köprülü Fazıl } \\
\text { Paşa Mektebi’ne } \\
\text { naklen }\end{array}$ \\
\hline 8 & $\begin{array}{l}\text { Osmangazi Mektebi } \\
\text { Mûsikî Muallimi }\end{array}$ & 300 & $\begin{array}{l}1 \text { Eylül 1919-11 Ekim } \\
1919\end{array}$ & $\begin{array}{c}\text { Kadrosunun teb- } \\
\text { dilinden Gekbu- } \\
\text { ze'ye naklen }\end{array}$ \\
\hline 9 & $\begin{array}{l}\text { Köprülü Fazıl Paşa Mektebi } \\
\text { Mûsikî Muallimi }\end{array}$ & 300 & $\begin{array}{c}15 \text { Ekim 1919-12 Ocak } \\
1920\end{array}$ & $\begin{array}{l}\text { Talebinden do- } \\
\text { layı naklen Os- } \\
\text { mangazi Numu- } \\
\text { ne Mektebi'ne }\end{array}$ \\
\hline 10 & $\begin{array}{l}\text { Osmangazi Mektebi } \\
\text { Mûsikî Muallimi }\end{array}$ & 300 & $\begin{array}{c}13 \text { Ocak 1920-1 Mart } \\
1921\end{array}$ & $\begin{array}{l}\text { Ahval-i sıhhiye- } \\
\text { sine mebni istifa } \\
\text { etmiştir. }\end{array}$ \\
\hline 11 & $\begin{array}{l}\text { Bayezid Mektebi } \\
\text { Mûsikî Muallimi }\end{array}$ & 300 & $\begin{array}{c}1 \text { Ocak 1923- } 1 \text { Şubat } \\
1923\end{array}$ & Naklen \\
\hline 12 & $\begin{array}{l}\text { Çandarlı Mektebi } \\
\text { Mûsikî Muallimi }\end{array}$ & 300 & 1 Şubat 1923- & - \\
\hline
\end{tabular}


5. Hatice Hayriye Hanım (1890 - ?) 1890 'da Ma'mûretü'l-Azîz'de doğmuştur. Nüfus İdare-i Umumiyesi mümeyyizlerinden emekli Tevfik Efendi'nin kızıdır. Özel eğitim görmüștür. 22 Nisan 1923'te görevine son verilmiștir (Sicil Dosyası, No: 759).

\section{Ahmed Cemil Bey (1901 - ?)} 1901'de İstanbul'da doğmuștur. Rasim Efendi'nin oğludur. İbtidâi tahsilini Üsküdar' daki özel Necm-i Terakki Mektebi ile Bayezid Rüșdiyesi'nde tamamlamıștır. Ardından İtalyan Ticaret Mektebi'nde iki buçuk sene okuduktan sonra Üsküdar Sultanîsi'ne devamla 7. sınıfından aldığı tasdikname ile mektebi terk etmiștir. Bilahare İstanbul Dârülmuallimîn-i
Ibtidâiyesi'ne girerek 31 Temmuz 1919'da a'lâ derecede șahadetname almıștır. 10 Şubat 1927'de, Galatasaray Lisesi muallimliğine naklinden dolayı vazifesinden ayrılmıștır (Sicil Dosyası, No: 730 ).
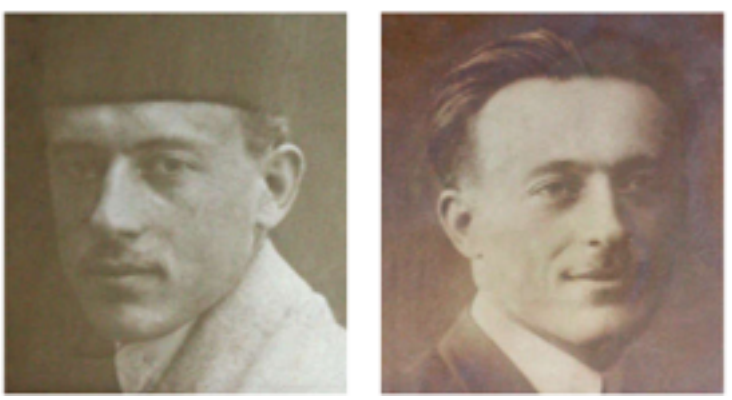

Resim 10. Ahmet Cemil Bey.

Tablo 23. Ahmet Cemil Bey'in çalıștığı kurumlar

\begin{tabular}{|c|c|c|c|c|}
\hline SN & Çalıştığı Mektepler ve Vazifesi & $\begin{array}{l}\text { Aldığı Maaş } \\
\text { Aylık Kuruş }\end{array}$ & $\begin{array}{c}\text { Göreve Başlama } \\
\text { ve Ayrılma Tarihleri }\end{array}$ & Açıklamalar \\
\hline 1 & $\begin{array}{c}\text { Selim-i Salis Mektebi } \\
\text { Mûsikî Muallim Vekilliği }\end{array}$ & 150 & $\begin{array}{l}22 \text { Ekim 1919-15 } \\
\text { Aralık } 1919\end{array}$ & $\begin{array}{l}\text { Aslının başla- } \\
\text { masından }\end{array}$ \\
\hline 2 & $\begin{array}{l}\text { Sokullu Mehmed Paşa Mektebi } \\
\text { Mûsikî Muallim Vekilliği }\end{array}$ & 150 & $\begin{array}{l}29 \text { Ekim 1919-31 } \\
\text { Aralık } 1919\end{array}$ & $\begin{array}{l}\text { Asaletinin } \\
\text { tasdikinden }\end{array}$ \\
\hline 3 & $\begin{array}{c}\text { Bebek Zükûr Darüleytamı } \\
\text { Muallimliği }\end{array}$ & 500 & $\begin{array}{l}3 \text { Kasım 1919-1 } \\
\text { Kasım } 1920\end{array}$ & $\begin{array}{l}\text { Mektebin lağ- } \\
\text { vindan dolayı }\end{array}$ \\
\hline 4 & $\begin{array}{c}\text { Sokullu Mehmed Paşa Mektebi } \\
\text { Mûsikî Muallimliği }\end{array}$ & 300 & $\begin{array}{c}1 \text { Ocak 1920-15 } \\
\text { Ekim } 1923\end{array}$ & $\begin{array}{l}\text { Hasbe't-teş- } \\
\text { kilat }\end{array}$ \\
\hline 5 & $\begin{array}{c}\text { Köprülü Fazıl Paşa Mektebi } \\
\text { Mûsikî Muallimliği }\end{array}$ & 300 & $\begin{array}{c}30 \text { Ocak } 1920-11 \\
\text { Aralık } 1920\end{array}$ & Ayrılmıştır. \\
\hline 6 & $\begin{array}{l}\text { Selim-i Salis Mektebi } \\
\text { Mûsikî Muallimliği }\end{array}$ & 300 & $\begin{array}{l}16 \text { Aralık 1920-15 } \\
\text { Ekim } 1923\end{array}$ & $\begin{array}{l}\text { Hasbe't-teş- } \\
\text { kilat }\end{array}$ \\
\hline 7 & $\begin{array}{l}\text { Altunizade Mektebi } \\
\text { Mûsikî Muallimliği }\end{array}$ & 300 & $\begin{array}{l}4 \text { Şubat 1920-30 } \\
\text { Eylül } 1921\end{array}$ & $\begin{array}{l}\text { Vazifesinin } \\
\text { lağvindan } \\
\text { dolayı }\end{array}$ \\
\hline 8 & $\begin{array}{c}\text { Barbaros Numune Mektebi } \\
\text { Mûsikî Muallimliği }\end{array}$ & 300 & $\begin{array}{c}10 \text { Ekim 1921-15 } \\
\text { Ekim } 1923 \\
\end{array}$ & $\begin{array}{l}\text { Hasbe't-teş- } \\
\text { kilat }\end{array}$ \\
\hline 9 & $\begin{array}{c}\text { Osmangazi, Selim-i Salis, Erenköy ve } \\
\text { Abdülhamid-i Evvel Mektepleri } \\
\text { Gınâ Muallimliği }\end{array}$ & 1.000 & $\begin{array}{l}16 \text { Ekim 1923-30 } \\
\text { Eylül } 1924\end{array}$ & $\begin{array}{l}\text { Hasbe't-teş- } \\
\text { kilat }\end{array}$ \\
\hline 10 & Osmangazi Mektebi Gınâ Muallimliği & 1.000 & $\begin{array}{c}1 \text { Ekim 1924-21 Mart } \\
1926 \\
\end{array}$ & Zammindan \\
\hline 11 & İstanbul 11. Mektep Muallimliği & 1.725 & $\begin{array}{l}22 \text { Mart 1926-10 } \\
\text { Şubat } 1927\end{array}$ & Nakil \\
\hline
\end{tabular}


Tablo 22. Hatice Hayriye Hanım'ın çalıștığı kurumlar

\begin{tabular}{|c|c|c|c|c|}
\hline SN & Çalıştığı Mektepler ve Vazifesi & $\begin{array}{c}\text { Aldı̆̆ı Maaş } \\
\text { Aylık Kuruş }\end{array}$ & $\begin{array}{c}\text { Göreve Başlama } \\
\text { ve Ayrılma Tarihleri }\end{array}$ & Açıklamalar \\
\hline $\mathbf{1}$ & $\begin{array}{c}\text { Hatice Sultan İnas Mektebi } \\
\text { Mûsikî Muallimeliği }\end{array}$ & $200 / 300$ & $\begin{array}{c}9 \text { Ekim 1918-30 Kasım } \\
1919\end{array}$ & İstifa etmiştir. \\
\hline $\mathbf{2}$ & $\begin{array}{c}\text { Selahaddin Eyyubi İnas Mektebi } \\
\text { Mûsikî Muallimeliği }\end{array}$ & 300 & - & Başlamamıştır. \\
\hline $\mathbf{3}$ & $\begin{array}{c}\text { Murad-1 Hamis İnas Mektebi } \\
\text { Mûsikî Muallimeliği }\end{array}$ & 300 & 15 Mart 1920-5 Ekim & Naklinden \\
\hline $\mathbf{4}$ & $\begin{array}{c}\text { Büyük Esma Sultan İnas Mektebi } \\
\text { Mûsikî Muallimeliği }\end{array}$ & 300 & $\begin{array}{c}22 \text { Eylül 1919-17 Kasım } \\
1921\end{array}$ & Nakil \\
\hline $\mathbf{5}$ & $\begin{array}{c}\text { Fatih İnas Numune Mektebi } \\
\text { Mûsikî Muallimeliği }\end{array}$ & 300 & 12 Şubat 1921-1 Ekim \\
1921 & $\begin{array}{c}\text { Devamsızlığ } 1 \\
\text { sebebiyle müstafi } \\
\text { sayılmıştır. }\end{array}$ \\
\hline $\mathbf{6}$ & $\begin{array}{c}\text { Moda İnas Numune Mektebi } \\
\text { Mûsikî Muallimeliği }\end{array}$ & 300 & $\begin{array}{c}19 \text { Kasım 1921-23 Mayıs } \\
1922\end{array}$ & Nakil \\
\hline $\mathbf{7}$ & $\begin{array}{c}\text { Adile Sultan İnas Mektebi } \\
\text { Mûsikî Muallimeliği }\end{array}$ & 300 & 15 Temmuz 1919-22 \\
Nisan 1923 & Azledilmiştir. \\
\hline
\end{tabular}

\section{Sonuç}

İstanbul'daki resmî ve özel eğitim kurumlarında farklı zamanlarda Gınâ, Mûsikî bazen Gınâ/Mûsikî muallimi ya da muallimeliği adıyla görev yapmış olan, 6'sı erkek 17'si kadın toplam 23 Gınâ/Mûsikî dersi öğretmeninin biyografisi ele alınmıștır. Ekte verilen tabloda sicil numarası, cinsiyeti, doğum yeri, baba mesleği, devlet hizmetine dâhil olduğunda göreve bașlama yașı, mezuniyeti, ehliyetname aldığı dersin adı, tayin edildiği kurumdaki branşı, erkek ise askerlik durumu, bildiği diller, görevden ayrılma tarihi ve gerekçesi ve toplam hizmet süresi gösterilmiștir.

Devlethizmetinde istihdamedilebilmenin ilk şartı, Gınâ/Mûsikî dersini hangi kademede tahsil ve talim edebileceğini gösteren ehliyetname sahibi olmaktır. Çalıșmadaki eğitimcilerinin; 9'unun Gınâ Ehliyetnamesi, 2'sinin Mûsikîi-i Rûhânî Birinci Sinıf Muallimlik Ehliyetnamesi, 6'sının Mûsikî Muallimeliği Ehliyetnamesi ve 6'sının da Mûsikî eğitimi almış oldukları görülmektedir. İstanbul Vilayeti Tedrisat-1 İbtidâiye Meclisi huzurunda yapılan imtihanda bașarılı olduktan sonra münhal olan muallimliğe tayin edilmişlerdir. Bunun dıșında Maarif-i Umumiye Nezareti Mûsikî Encümeni, Dersaadet Ermeni Patrikhanesi Maarif Komisyonu, Dârülelhan Mûsikî Encümeni ve Șark Mûsikî Cemiyeti'nin açılmış olan imtihanlar neticesinde verilmiș olan ehliyetnameler de geçerli olmuștur.

Gınâ/ Mûsikî, piyona, keman ve nota olarak talim ve tedris edilen dersin haftada iki ya da dört saat gibi ders saatinin az olması dolayısıyla aylık maașların 200 kuruş daha sonra 300 kuruş olduğu görülmektedir. Haftalık ders saatlerinin ve ücretinin yetersizliği dolayısıyla, dersin mualliminin açık olduğu diğer iki üç eğitim kurumunda da görev yapmıș oldukları ve ücret almıșlardır. Geçimlerini sağlamak maksadiyla, muallimlik görevlerini aksatmamak kaydıyla, konser heyetinde 
bulunan, özel eğitim kurumlarında veya birebir özel keman, piyano ve mûsikî dersi verenler olmuștur. Derslerine muntazam olarak gelmeyenler önce ihtar edilmiș ardından görevlerinden azledilmiștir. 15 Ekim 1923'te, teșkilatta yapılan değișiklik neticesinde mûsikî muallimliği müsabaka sınavında başarılı olamadığından ya da sınava girmeyenler müstafi kabul edilmiş ya da açıkta kalmıştır. 1 Kasım 1929'da muallimler meslek ve alanlarıyla ilgili kurslara alınmıștır. Bu kursta bașarılı olamayanların görevine son verilmiștir. 30 Eylül 1931'de yapılan Devlet imtihanında başarılı olmayanlar ise meslekten ihraç edilmiștir. Bunun dıșında alan değișikliği yapanlar, farklı eğitim kurumuna geçenler ve meslekten istifa ederek ayrılanlar olmuștur.

\section{KAYNAKÇA}

Arşiv Kaynakları

BOA, Y.EE, 112/6, (24 C.ahir 1286/1 Eylül 1869).

İstanbul Milli Eğitim Müdürlüğü Zeytinburnu Arşivi

Personel Sicil Dosyası, No: 12, No: 20, No: 22, No: 25, No: 61, No: 65, No: 501, No: 505, No: 522, No: 536, No: 572, No: 611, No: 616, No: 624, No: 649, No: 730, No: 739 , No: 759 , No: 787 , No: 853 , No: 940, No: 957, No: 990.

\section{Kitap ve Makaleler}

Akyıldız, A. (1993), Tanzimat Dönemi Osmanlı Merkez Teșkilatında Reform (1836-1856). İstanbul: Eren Yayınları.

Arslan, A. (2004), “Darülfünun'dan İstanbul Üniversitesi'ne", İstanbul Sempozyumu 2003.
Güçtekin, N. (2015). İstanbul'daki Husûsi Mektepler (1873-1922). İstanbul: IBB Kültür AȘ.

Güçtekin, N. (2015), “ilk Türk Mûsikî Cemiyeti: Dârülmûsikî-i Osmanî Cemiyeti (Mektebi) ve Faaliyetleri (1908-1914)". Rast Müzikoloji Dergisi, Cilt III, Sayı 1.

Kaçar, M. (1996), Osmanlı Devleti'nde Bilim ve Eğitim Anlayıșındaki Değișmeler ve Mühendishânelerin Kurulușu. Basılmamış Doktora Tezi, İstanbul Üniversitesi Bilim Tarihi Anabilim Dalı.

Özcan, N. (1999), “Ahmet Irsoy”. Türkiye Diyanet Vakfı İslâm Ansiklopedisi, C. 19, İstanbul: Türkiye Diyanet Vakfı Yayınları.

Özcan, N. (2013), “Zekâi Dede” Türkiye Diyanet Vakfı İslâm Ansiklopedisi, C. 44, İstanbul: Türkiye Diyanet Vakfı Yayınları.

Özden, E. (2018), “Arșiv Belgeleriyle Dârülelhan”. Konservatoryum, C. 5, Sayı: 1.

Şakar, M. ve Güçtekin, N. (2018), Maariften Milli Eğitime İstanbul Sicilleri (1878-1965). C. I - II, III, İstanbul: Milli Eğitim Bakanlığı Destek Hizmetleri Yayını.

Şentürk, N. (2001), “Musikî Muallim'den Günümüze Müzik Öğretmeni Yetiștiren Kurumlar", G.Ü. Gazi Eğitim Fakültesi Dergisi, Cilt: 21, Sayı: 2.

Toker, H. ve Özden E. (2013), “Osmanlı Devletinde Müzik Eğitimi Veren Önemli Kurumlar". Rast Müzikoloji Dergisi, Cilt: I, Sayı: 2. 


\section{Talimatnameler}

Darülirfan Mektebi'nin Resm-i Tevzi-i Mükâfat Cetveli. (1318/1902). İstanbul:

Hanımlara Mahsûs Gazete Matbaası.

Tedrisât-ו İbtidâiye Kanun ו Muvakkati. (23 Eylül 1329/6 Ekim 1913), Düstûr, İkinci Tertip, C. V, s. 804-823.

Maarif-i Umumiye Nezareti Telif ve Tercüme Dairesi, (25 Nisan 1331/8 Mayıs 1915). Mekâtib-i Sultaniye Ders Programı, İstanbul, Matbaa-i Amire.

Internet

http:/www.turksanatmuzigi.org. (2017, Eylül 1). 


\begin{tabular}{|c|c|c|c|c|c|c|c|c|c|c|c|}
\hline 离: & & & ' & ' & ' & ' & ' & 1 & 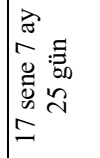 & ' & \\
\hline 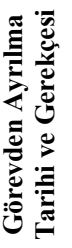 & 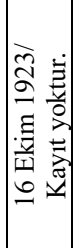 & 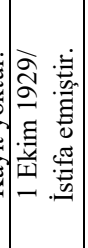 & 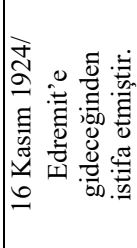 & 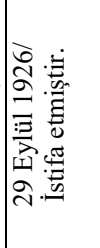 & 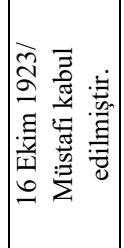 & 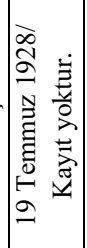 & 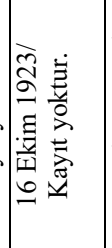 & 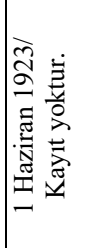 & 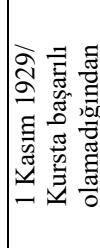 & 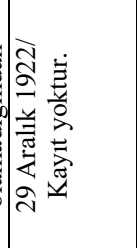 & 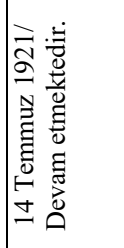 \\
\hline רٕ) & ' & 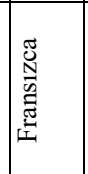 & I & ' & ' & 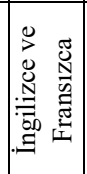 & . & ' & ' & 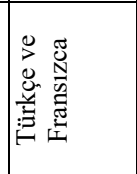 & 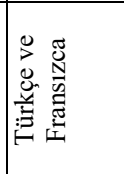 \\
\hline 产 & & ' & ' & ' & ' & ' & ' & ' & ' & ' & ' \\
\hline 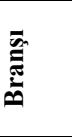 & 丞 & $\mid \frac{G}{\overline{7}}$ & 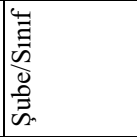 & 范 & 节 & 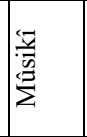 & 节 & 吾 & 点 & 吾 & 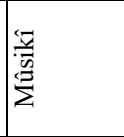 \\
\hline 竧 & 节 & 节 & 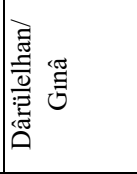 & $\stackrel{\leftrightarrow}{\exists}$ & 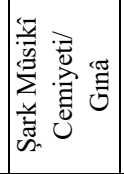 & 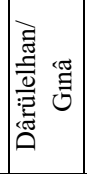 & 苛 & 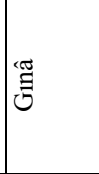 & 节 & 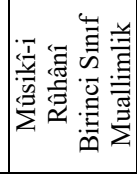 & 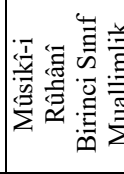 \\
\hline 离 & 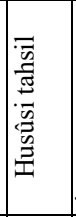 & 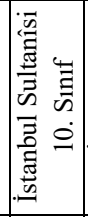 & 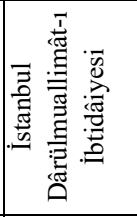 & 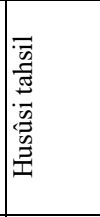 & 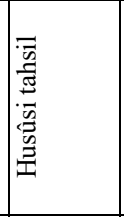 & 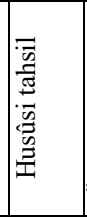 & 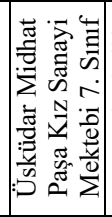 & 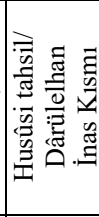 & 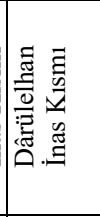 & 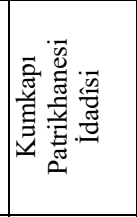 & 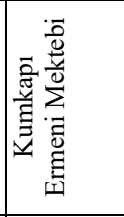 \\
\hline 范 & 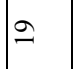 & $\infty$ & $\bar{\sim}$ & $\hat{\sim}$ & $\hat{m}$ & $\hat{\imath}$ & $\infty$ & $\approx$ & 商 & $\stackrel{\sim}{\sim}$ & $\stackrel{\infty}{\stackrel{\infty}{+}}$ \\
\hline 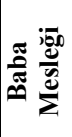 & ح. & $\stackrel{i=}{\bar{\pi}}$ & 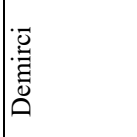 & 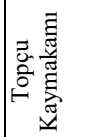 & 录 & 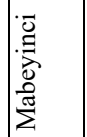 & 窇 & 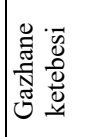 & 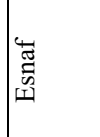 & 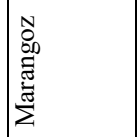 & 事 吾 \\
\hline 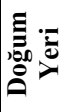 & 层 & 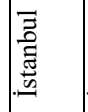 & 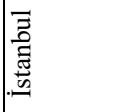 & 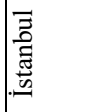 & 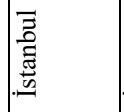 & 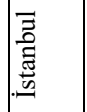 & : & 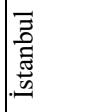 & 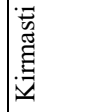 & 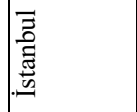 & 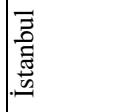 \\
\hline u & $\simeq$ & 山 & $\simeq$ & $\triangle$ & $\triangle$ & 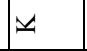 & $\triangle$ & $\triangle$ & $\triangle$ & I & 피 \\
\hline 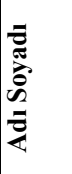 & 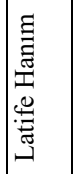 & 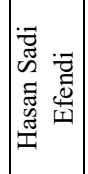 & 莺 駦 & 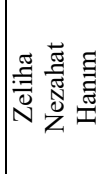 & 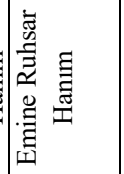 & 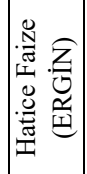 & & 窟志 & 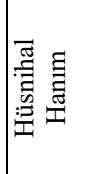 & 总密总 & 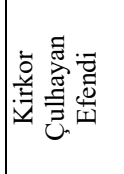 \\
\hline$\frac{\overline{\bar{v}}}{\bar{s}} \bar{z}$ & $\underset{\mathrm{N}}{\mathrm{i}}$ & $\approx$ & ते & $\hat{n}$ & กี & $\approx$ & \&্ণ & $\approx$ & in & $\underset{n}{0}$ & $\underset{\widetilde{J}}{\mathbb{J}}$ \\
\hline Z & - & N & m & $\nabla$ & in & 0 & r & $\infty$ & a & $\Theta$ & $=$ \\
\hline
\end{tabular}




\begin{tabular}{|c|c|c|c|c|c|c|c|c|c|c|c|c|}
\hline : & 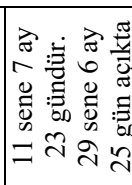 & & ' & ' & 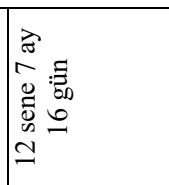 & & & & ' & ' & I & ' \\
\hline 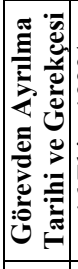 & 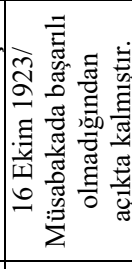 & 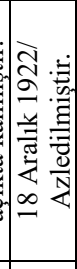 & 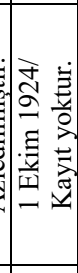 & 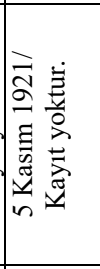 & 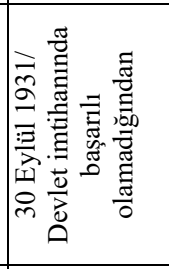 & 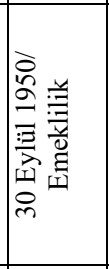 & 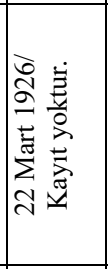 & 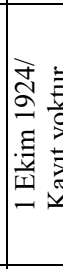 & 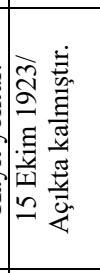 & 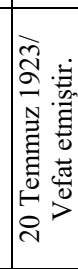 & 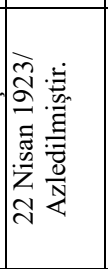 & 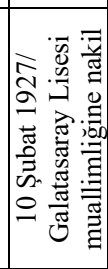 \\
\hline 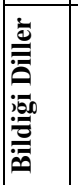 & ' & ' & ' & I & ' & 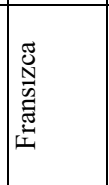 & ' & ' & ' & 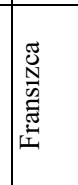 & ' & ' \\
\hline 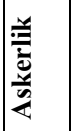 & ' & ' & ' & I & ' & ' & 1 & ' & 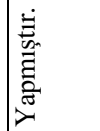 & ' & ' & ' \\
\hline 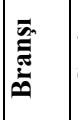 & 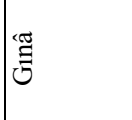 & 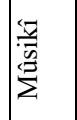 & 莺 & 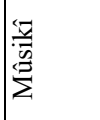 & 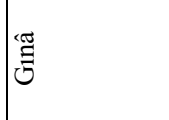 & 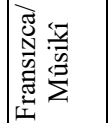 & 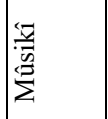 & छَّ & 离 & 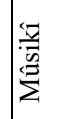 & 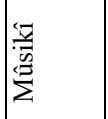 & $\frac{5}{5}$ \\
\hline 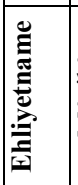 & 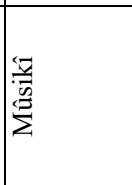 & 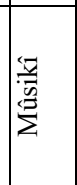 & $\frac{5}{50}$ & 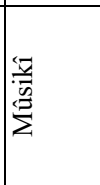 & 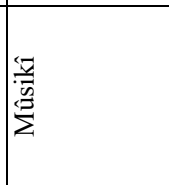 & 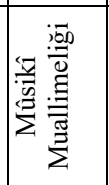 & & & 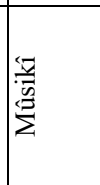 & & I & ' \\
\hline 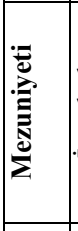 & 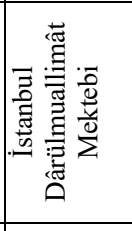 & 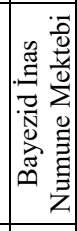 & & 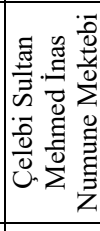 & 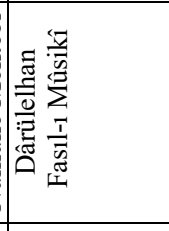 & 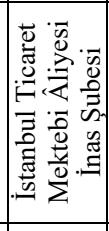 & 急 & 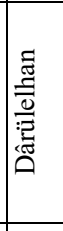 & 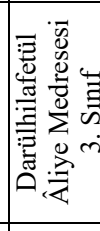 & 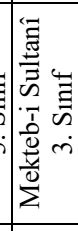 & 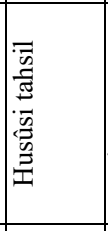 & 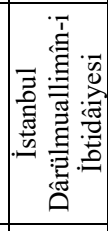 \\
\hline ثึ & \pm & iิ & if & $=$ & 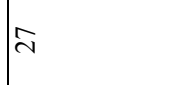 & $\cong$ & $\stackrel{\infty}{\sim}$ & q & ส & $\approx$ & $\infty$ & 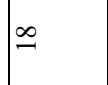 \\
\hline 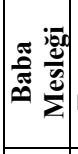 & 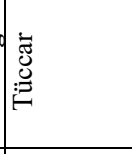 & o. & a. & 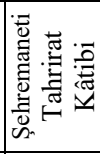 & 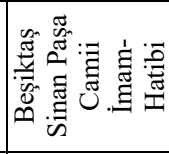 & 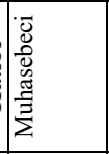 & ar. & r. & 竘 & 疍: & 弪 & a. \\
\hline . & 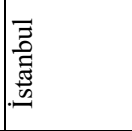 & 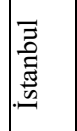 & 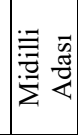 & 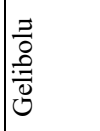 & 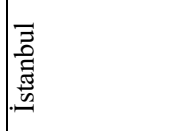 & 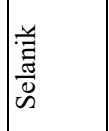 & 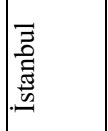 & 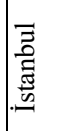 & 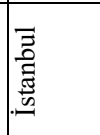 & 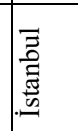 & 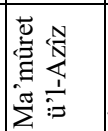 & 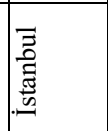 \\
\hline U & $\simeq$ & $\because$ & 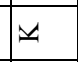 & $\simeq$ & $\because$ & $\because$ & $\because$ & $\triangle$ & $\Phi$ & 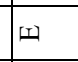 & $\simeq$ & س \\
\hline 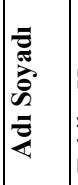 & 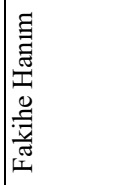 & 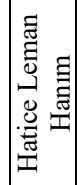 & 咅 & 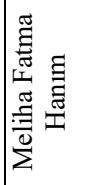 & 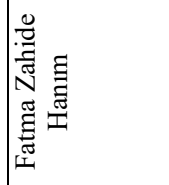 & 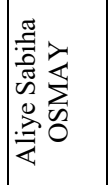 & 量总 & 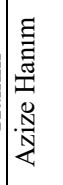 & 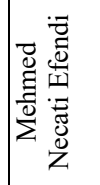 & 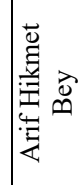 & : 总高 & 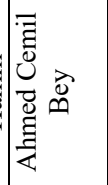 \\
\hline 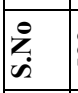 & స్ন & वे & 5 & $\approx$ & $\overline{6}$ & 恕 & 2 & $\stackrel{\infty}{\infty}$ & हे & $\frac{0}{6}$ & हे & $\stackrel{i}{\approx}$ \\
\hline z & $\approx$ & 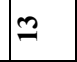 & \pm & 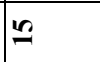 & $\simeq$ & $I$ & $\infty$ & 2 & సิ & $\bar{N}$ & $\approx$ & $\approx$ \\
\hline
\end{tabular}




\section{Biographies of gina-musiki teachers in İstanbul Maarif Registers (1894-1931)}

\section{Extended Abstract}

The three-volume work entitled Maariften Milli Eğitime ìstanbul Sicilleri (Istanbul Registries from Maarift to National Education) (1878-1965), which was addressed based on the Ottoman register files of 627 personnel in the Zeytinburnu Registry Archive of Istanbul Directorate of National Education, also constitutes the first bibliography published for educators.

In this study, the biographies of 23 educators, who were employed in public service as Gınâ, GınâMûsikî, or Mûsikî teachers in official and general education institutions at the primary, secondary, and high school levels in Istanbul during the last period of the Ottoman Empire and the first decade of the Republic, were included based on the work published. With new documents, information, and findings, it was attempted to contribute to the literature on the History of Turkish Music and Ginâ/ Mûsikî education in schools.

The primary education institution of the Ottoman Empire in the classical period was madrasahs. Madrasahs that were successful during the establishment and development periods played a significant role in the Ottoman Empire becoming a world state. In addition to administrators' preferences for Western education institutions, the inadequacy of madrasahs that could not produce alternatives while new expansions were made in the European model and their failure to keep their former positions played a significant role in the Tanzimat period during which the Ottoman Empire was subjected to European-style reforms. This process resulted in the opening of European-style institutions at the university level and primary, secondary, and high school levels. In a sense, the fall of madrasahs caused the Ottoman Empire to become a state that could not renew its institutions within the framework of its civilization and that established new institutions by importing from elsewhere.

Along with the declaration of the Constitutional Monarchy on July 23, 1908, all segments of society in the Ottoman Empire were rapidly engaged in an organizing process. Hundreds of associations were established, and publications were issued. The music lessons that were given in the classrooms of Enderûn, Mevlevihane, Mehter, and Muzıka-i Hümâyun before the second Constitutional Monarchy were first given in the music associations and schools opened after the second Constitutional Monarchy. Dârülmûsikî-i Osmanî Cemiyeti (the Ottoman Music Association), which was opened in the field of music in 1908, was the first music association established in the Ottoman Empire. Turkish music masters and music lovers gathered for the first time under the roof of the Ottoman Music Association. After a while, İsmail Hakkı Bey left this association in March 1909 and established the Mûsikîi Osmanî Cemiyeti (the Society of Ottoman Music). Thus, musical activities were maintained through these two societies during the second Constitutional Monarchy period. The Society of Ottoman Music and the Ottoman Music Association ended their activities in 1910 and 1912, respectively, and they became a school. During these years, the mentioned associations gave paid music lessons and organized concerts, entertainment, and performances in Istanbul. Furthermore, they attempted to continue their activities with the financial support of important or wealthy people of that period. Between 1912 and 1914, Turkish music developed due to the demand of the rich and the upper class. During this period, the number of music lessons, concerts, night programs, school numbers and activities increased. This development of Turkish music education ended with the beginning of World War I. The harsh conditions of the war period affected all fields. Turkish music was also affected by them.

The popularity of Turkish music had an effect on the Music lesson becoming a part of the curriculum in all schools under the name of "Gınâ." With the Tedrisat- İbtidâiye Kanun- ו Muvakkati (the Temporary Law of Primary Education) on October 6, 1913, primary schools were extended from three to six years. Among the lessons to be taught in primary education, there were six hours of Ginâ lessons per week, 1 hour in each classroom. In 1915, three hours of Ginâ lessons, one hour each, were also added to the 
6th, 7th, and 8th grades in the Mekatib-i Sultâniye Curriculum.

This study was prepared based on the biographies of the educators who taught Gınâ/Mûsikî in the work entitled "Maariften Milli Eğitime İstanbul Sicilleri (Istanbul Registries from Maarift to National Education) (1878-1965)", which was addressed based on the Ottoman register files of 627 personnel in the Zeytinburnu Registry Archive of Istanbul Directorate of National Education and also constitutes the first bibliography published for educators. Nevertheless, the file-style documents of the Ministry of Education in the Prime Ministry Ottoman Archives on the History of Turkish Music from Tanzimat to the first decade of the Republic and the Gınâ/Mûsikî education in schools, and the literature found in other sources were determined.

The biographies of a total of 23 Ginâ/Mûsikî course teachers consisting of 6 males and 17 females, who worked under the name of Ginâ, Mûsikî and sometimes Gınâ/Mûsikî teachers at different times in official and private education institutions in Istanbul, were discussed. The registration number, gender, place of birth, father's occupation, age at the start of service when involved in public service, graduation, name of the course for which certificate was received, branch in the institution to which they were appointed, military status if male, languages they spoke, date and reason for leaving office, and total service time are presented in the attached table.

The first condition to be employed in public service was to have a certificate indicating at which level Gınâ/Mûsikî lesson could be studied and practiced. It is observed that while 9 of the educators in the study had the Ginâ certificate, 2 of them had the Mûsikî-i Rûhânî First Class Teacher's certificate, 6 of them had the Mûsikî Teaching certificate, and 6 of them received music education. They were appointed as intern teachers after being successful in the exam held in the presence of the Istanbul Vilayeti Tedrisat-ו İbtidâiye Meclisi (Istanbul Province Primary Education Council). Moreover, the certificates given as a result of the examinations of the Maarif-i Umumiye Nezareti Mûsikî Encümeni (the Ministery of Public Education Music Commission), Dersaadet Ermeni Patrikhanesi Maarif Komisyonu (Dersaadet Armenian Patriarchate Education Commission), Dârülelhan Mûsikî Encümeni (Dârülelhan Music Commission), and Şark Mûsikî Cemiyeti (Oriental Music Society) were also valid.

\section{Keywords}

gınâ-mûsikî teacher, history of turkish music, gınâ-mûsikî education, faize ergin, laika karabey, kirkor mehteryan, kirkor çulhayan, arif hikmet bey. 